\title{
Emerging Factors Shaping Identity of Indigenous Urbanism Concurrently Adopting Modernity in Qatar: The Application of Diffusion Theory
}

\section{Salim Ferwati ${ }^{1}$ | Rana Salman Wadi ${ }^{2}$ | Omar Ferwati ${ }^{3} \mid$ Ali Keyvanfar ${ }^{4} \mid$ Arezou Shafaghat ${ }^{5}$}

Received: 2019-05-20 | in its final version: 2019-07-13

Abstract Forms, designs, and symbols are the components of built environment, which transfer the information of place and identity to users. This research aimed to explore the emerging factors shaping the identity of local urban districts while adopting the global culture and modernity. To achieve this aim, the research has conducted two phases within which include a few steps. Phase one was to explore different urban zoning. It includes a detailed analysis of the different architectural styles and elements that have spread the identity concerning the main constituents of urban zones. Because of the difficulty to survey the whole Doha region, this research has focused on four mega projects with different characteristics in Doha Governorates; Pearl Qatar (representing Islamic architecture), Souq Waqif (representing traditional architecture), Msheireb project (as the combination of traditional and modern architecture), and West Bay (as the reference for global approach). Phase one has two steps; Field Observation and Field survey. Phase two was to explore the new elements spread for built environment's identity with the concentration on the selected sites in Doha. Phase two has two steps; Photo survey and Interviews. To test the proposed premise, this phase prolonged into human geography using Torsten Hagerstrand's diffusion theory. The findings of this research help architects and urban designers to enhance susers' awareness of their natural environment, and provide a better perception of identity in local urban districts and vernacular architecture, based on instinct and strategic view derived from the global culture and societal modern architecture principles.

Keywords: Indigenous architecture; contemporary design; modern design; urban design

Citación

Ferwati, M. S. et al. (2020). Emerging Factors Shaping Identity of Indigenous Urbanism Concurrently Adopting Modernity in Qatar: The Application of Diffusion Theory. ACE. Architecture, City and Environment, 14(42), 8362. DOI: http://dx.doi.org/10.5821/ace.14.42.8362

${ }^{1}$ Degree in Cultural/Behavioural Geography, Ph.D., Department of Architecture and Urban Planning, College of Engineering, Qatar University (ORCID: 0000-0002-0530-4180, Scopus ID: 57063299000), ${ }^{2}$ Engineer, Department of Architecture and Urban Planning, College of Engineering, Qatar University, ${ }^{3}$ School of Architecture, Waterloo University, ${ }^{4}$ Ph.D., College of Architecture and Construction Management, Kennesaw State University (ORCID: 0000-0003-0059-274X, Scopus ID: 55326089900), ${ }^{5}$ Architect, Ph.D., Institute of Research and Development, Duy Tan University (ORCID: 0000-0002-6439-936X; Researcher ID: B-8011-2016; Scopus ID: 55326539000). Contact: sferwati@qu.edu.qa, arezou@utm.my

ACE, 14 (42) CC BY-ND 3.0 ES | UPC Barcelona, España | Emerging Factors Shaping Identity Of Indigenous Urbanism Concurrently Adopting Modernity In Qatar: The Application Of Diffusion Theory. DOI $\underline{\text { http://dx.doi.org/10.5821/ace.14.42.8362 }}$ 


\section{Introduction}

Organizers, designers, and specialists assigned an amazing scope of conceivable references established for customary town and neighborhood arrangement and configuration in vernacular design (Al-Sayyad, 1999). Cases of such references might be significant to comfort, security, open space configuration, house plan, and gathering design, atmosphere control, Ergonomic scaling, light and development strategies, and local materials (Knight and Haslam, 2014; Lamit et al., 2013b; Shafaghat et al., 2015). Indeed, the organizers, designers, and specialists can improve social identity, personality and progression inside the texture of new urban and outside the old center. They should pick deliberately among these references and adjust them as indicated by the nearby authentic foundation, neighborhood social conventions, and the specific situations (Erickson and Roberts, 1997; Hagusser et al., 2012; Taha, 2013).

Concerning style and plan, the new structures ought not to be composed in a tasteless worldwide style. They ought to be worked by neighborhood engineering plan rules using indigenous building materials. By joining current building ideas and innovation with customary styles and structures, openings can be made for the new engineering to exist together with the old (Shafaghat et al., 2016c). Likewise, because no building remains solitary in the urban texture, the building outline and gathering should offer structures to new urban spaces, so they may give a binding system to gather various design styles and structures (Furlan, 2016; Furlan and Faggion, 2015). It is critical to save the legitimate character of the old center and urge the innovative and versatile re-utilization of its old structures to fit new needs and keep the center alive (Furlan and Faggion, 2015).

The urban and its structural characters distinguish an iconography of the place. The urban and its engineering characters gives a feeling of progression with the authentic setting, and the reinterpretation of customary design exhibits a dominance of building procedures and a profound comprehension (Ishii et al., 2010). Using the updated materials and innovation does not ignore the peaceful feeling of regionality. The engineer builds a cutting-edge urban complex while holding the substance of its conventional casing; this turns into a momentous accomplishment. The supported endeavors and responsibility of experts and leaders toward the production of a character is a key part in the continuation of conventional design and developing a responsive urban (Ibrahim, 2013).

Indeed, there is an absence of connection between the traditional architecture design principles and the characteristics of the modern cities (Hamdan, 1962; Hakim, 1985). Traditional architecture has an immediate connection with history and self, while contemporary architecture represents the sole of a new generation. The integration of both styles leaves the imagination of the space makers wide open while keeping in mind that the local architecture carries aspects for the place identity (Chavoya Gama, 2016). Genuine social manageability will be accomplished through the mix of nearby identity into urban improvement. This may be the main reason behind the economic, social and identity crisis of the urban communities in modern cities (Lapidus, 1973; Schmitt et al., 2010). For example, this problem can be demonstrated by cities in the Maghreb, especially Algeria, where cultural and identity disputes faced crisis greatly affecting the security situation. Hence, there is an essential need to apply the principles of traditional cities to bring our cities back to the livability (Saoud, 1997). Identity of the place is defined by Lynch in 1981 as "the extent to which a person can recognize or recall a place as being distinct from other places - as having a vivid, or unique, or at least a particular, character of its own" (Southworth and Ruggeri, 2010). The need for place identity leads to the creation of distinctive traditional design elements and their new application.

Referring to the issues mentioned above and concerns, this research aimed to explore the emerging factors shaping the identity of traditional urban districts while adopting the global culture and modernity. To achieve this aim, the research has engaged two objectives. The first objective is to

ACE, 14 (42) CC BY-ND 3.0 ES | UPC Barcelona, España | Emerging Factors Shaping Identity Of Indigenous Urbanism Concurrently Adopting Modernity In Qatar: The Application Of Diffusion Theory. DOI: http://dx.doi.org/10.5821/ace.14.42.8362 
investigate traditional and contemporary physical urban and architectural styles and elemental design that evoke the built environment's identity. The second objective is to investigate the adoptation of new ideas and factors that shaped the current built environment's identity. This research has scoped in Doha, Qatar, while the findings can be generalized somewhat to similar cases and countries. As the case study of this research, Qatar like numerous different nations is worried about the loss of urban and structural identity and personality by the heartless pulverization and hopeless loss of indigenous urban and engineering characters, which has been propagated by the fast rush of urban improvement (Toth, 1993). Qatar has been built up based on a national vision to fortify the traditional neighborhood identity and indigenous urban character. Qatar National Vision 2030 forms a scaffold between the present and future (Figure 1). It states, "Qatar will try to fabricate a protected, secure and stable society in light of powerful organizations.

The nation will advance resilience, consideration, productive exchange, and receptiveness toward different societies concerning its Arab and Islamic character. Also, it will give its residents their essential needs and assurance them rise to circumstances" (Qatar National Developments Strategy, 2011). As indicated by Furlan and Petruccioli (2016), Doha's urban development has advanced a moderate rate of improvement, administrations, and lodging ventures. The moderate rate of urban improvement was generally credited to the nation's moderately insecure work advertise. The references relate this unsteadiness to the nation's oil-based economy (Furlan and Petruccioli, 2016).

Figure 1. Urban development of Doha: in 1937 (left) 1959 (middle), and 2018 (right)

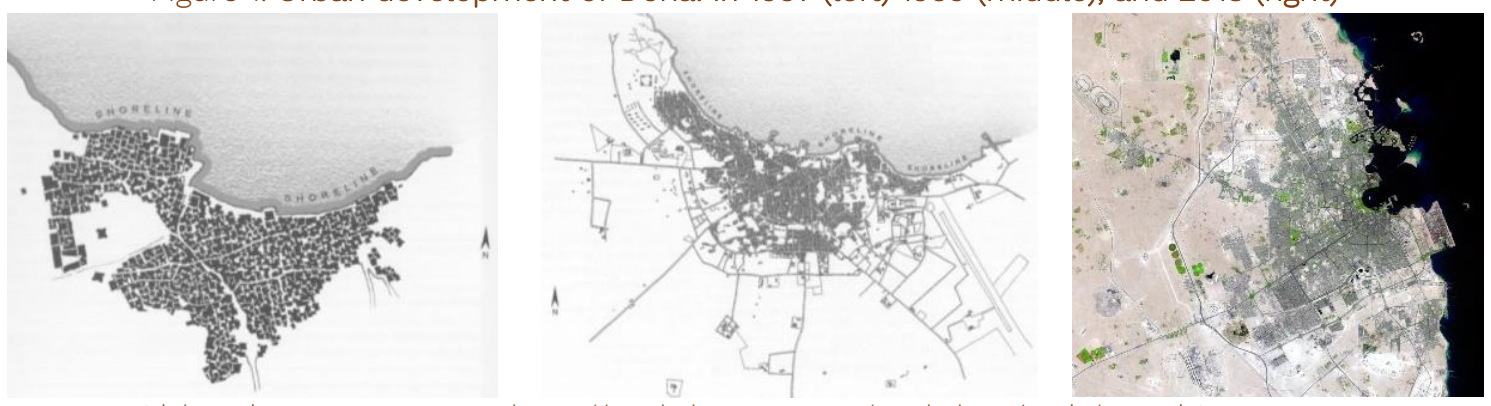

Source: Jaidah and Bourennane, 2010. https://earthshots.usgs.gov/earthshots/node/69\#ad-image-0-5

\section{Literature Review}

\subsection{Qatari Architecture and Built Environment}

\subsubsection{Qatari Vernacular Architecture}

Qatar has traditional architectural components and indigenous urban design concerns. The following presents them, in detail.

i) Urban oasis settlements: In Qatar, traditional oasis settlements were usually placed close to the oasis on land. A ring of walls made up of mud and stones used to surround the settlements for protection from attacks. Therefore, urban growth was limited to the boundaries of this protective rings (Salama and Wiedman, 2013). Large gates on different sides of the surrounding walls were entrances and existing to the settlement (see Figure2a). The winding main streets often made crooked by the random unplanned construction and placing of private dwellings, fanned out from the gates and normally intersected in the center of the settlement.

ii) Compact neighborhoods: According to Salama and Wiedman (2013) neighborhoods (or, fareej) can be defined as urban cells that resulted from a group of branching side streets, that ended

ACE, 14. (42) CC BY-ND 3.0 ES | UPC Barcelona, España | Emerging Factors Shaping Identity Of Indigenous Urbanism Concurrently Adopting Modernity In Qatar: The Application Of Diffusion Theory. DOI: http://dx.doi.org/10.5821/ace.14.42.8362 
in the cellular arrangement of houses (see Figure 2b). Smaller roads led from the main roads to the local neighborhoods and private housing of the towns. These small roads usually had the width of one packed camel while their height was tall as courtyard walls. The tight spaces between buildings had two major purposes, first, to maximize land use within the settlement and, second, to provide cooling and welcome shade. The proximity of the buildings and walls of houses were used as natural protection from the sun. Also, the network of narrow side roads and dead-end alleys served to reinforce the privacy character of neighborhoods (Salama and Wiedman, 2013).

iii) Gated neighborhoods: Some neighborhoods were protected by secondary gates from the rest of the main gates of the town, anticipating the preference for the gated communities (see Figure 2c).

iv) Sabat: In some cases, it was common to have a link from the first floor to the neighboring house, which was called sabat. The sabat provided a shaded area for the streets underneath and extended the private living spaces (Salama and Wiedman, 2013) (see Figure 2d).

v) Local building materials: As Salama and Wiedman (2013) have mentioned that the architectural form was usually determined by the available local building materials; for example, along the coast, available coral stone and gypsum were used for constructing the walls of the settlements. Barasti huts, which were simple structures, made of date palm fronds were used by low-income families for a living. Furthermore, inland adobe could be found along the wadis, was used as a basic building material for walls and ceilings; these were supported by strong beams made of palm trunks. Adobe also could balance the indoor temperature because of its good natural insulation properties and its ability to absorb air moisture.

vi) Market (or souq): The traditional market is extended linearly, often sheltered and shaded by adjoining roofs (Salama and Wiedman, 2013). Markets in oasis towns were generally the public spaces, where mosques were the center or focal point of the town.

vii) Privacy: Traditional architecture and urban design in Qatar had important design considerations for privacy and territoriality. Spaces were divided according to the use, where male visitors are separated from family. The Majlis (or reception hall) was used for gatherings of family members to discuss religious or community issues (Salama and Wiedman, 2013). Accessibility was so important where the majlis access route is always different from the family territory. The general qualities of housing groups represent unified units. It is a result of the common structural module of the courtyard (Jaidah and Bourennane 2010) (see Figure 2e).

viii) Climate-responsive housing: Qatari architecture was highly influenced by the weather and geographical nature. Rainfall is light, but in certain areas, humidity can be very high. Accordingly, roofs are flat and always aim to provide shade in spaces leading to rooms and courtyards to provide thermal comfort. Window openings were rectangular and small compared to the size of the wall, making almost blind facades. In ordinary rooms, the windows look out into the courtyards. Regarding the Majlis and upper rooms, the windows open onto the courtyards and streets (Jaidah and Bourennane 2010).

ix) Mosque: According to Hakim (1985), the central core of urban was usually characterized by an ensemble of mosque, courthouse, and palace. According to Jaidah and Bourennane (2010) mosques in Qatar are simple, they include the main components of mosques which are: Mihrab, that indicates the direction of Mecca, an entrance Saban and Burj for the calling of prayer (see Figure 2f).

x) Military buildings: Military buildings in Qatar are divided into two categories. 1) The fortified structures usually within the colonial period, which developed a character of protection. This fortification has a form of machicolation with a limited function and has two levels of 'ayyin' to look through outside. 2) The fortified house which has a special feature of two watch towers (Jaidah and Bourennane 2010). The courtyard type of development was constructed with tall circular towers at the corners of the structure to give greater security. The towers were rounded

ACE, 14 (42) CC BY-ND 3.0 ES | UPC Barcelona, España | Emerging Factors Shaping Identity Of Indigenous Urbanism Concurrently Adopting Modernity In Qatar: The Application Of Diffusion Theory. DOI: $\underline{\text { http://dx.doi.org/10.5821/ace.14.42.8362 }}$ 
as the desert stones are relatively small and can hardly be bonded together (Jaidah and Bourennane 2010) (see Figure 2g).

xi) Ornamentations: According to Jaidah and Bourennane (2010), the houses in Qatar and the Gulf states were characterized with the carved gypsum decorations, mostly of geometrical style, and sometimes plant pictures. The same applies to the wooden doors, particularly its peaks, and windows. Windows might be decorated with a glass of brilliant colors. They were either geometrical or plant figures decorations being carved in specific places and organized in the form of rectangular, lobed or semi-circular panels. This is in addition to various types of friezes under the level of wooden roof (Jaidah and Bourennane 2010; Shafaghat et al., 2016a; Shafaghat et al., 2016b).

xii) Wind catcher (or wind tower): This architectural element for natural ventilation is made of a narrow rectangular openings helped to cool down the indoor temperature (Salama and Wiedman 2013). According to Jaidah and Bourennane (2010), Qatari architecture shared some similarities with Iranian architecture. Those examples could be seen on the coast, where builders came from Iran or were influenced by its architecture. Badjeer, which are openings for ventilation and sunlight, are mostly found in Majlis and the upper rooms, but not on the ground floor (Jaidah and Bourennane 2010) (see Figure 2h).

Figure 2. a) Structure of oasis settlements, b) structure of traditional neighborhoods, c) gated neighborhood in Riyadh, d) Traditional sabat in Riyadh (Source: Salama and Wiedman, 2013), e) Sketch perspective of Mohammed Naserallah House, f) Abu Manaratain Mosque (Al-Wakrah) 1940,

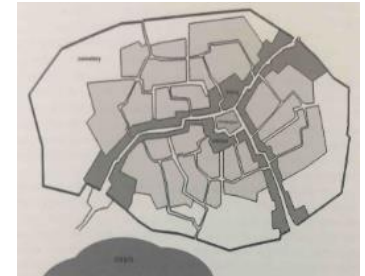

(a)

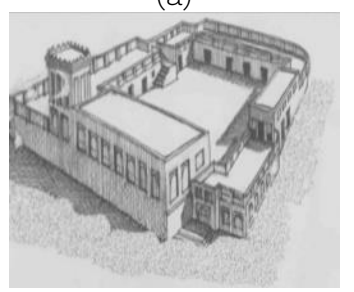

(e)

\section{g) Perspective sketch of Al-Zubarah fort}

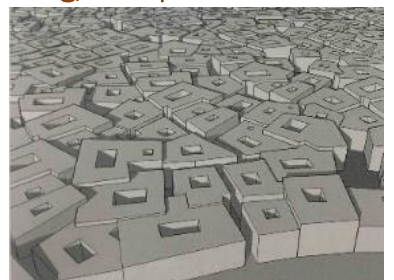

(b)

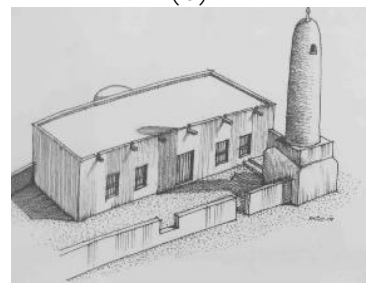

(f)

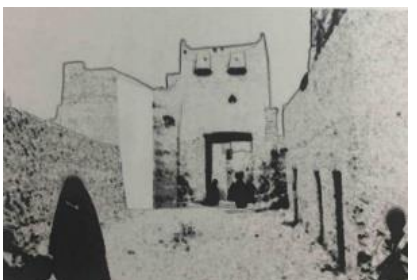

(c)

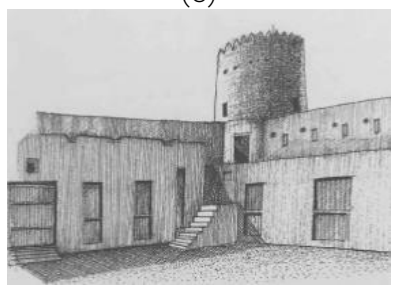

(g)

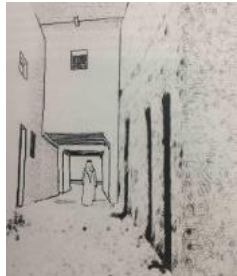

(d)

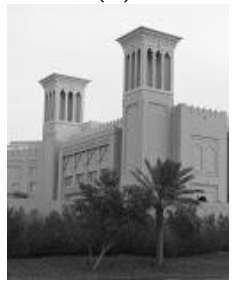

(h)

Source: http://stephencfchan.blogspot.com/2015/05/doha-wind-catchers.html)

\subsubsection{Qatari Contemporary Architecture}

Contemporary engineering is hard to distinguish because it could not be perceived as a reasonable style in entire Qatar as well as in the little neighborhood (Antarikananda et al., 2006). Current engineering period was in the right on time to mid-twenty centuries and known for its perfect lines. Antarikananda et al. (2006) expressed that Qatar contemporary engineering turns into a case of internationalism. Internationalism implies killing the neighborhood convention to worldwide masses, which had no character or mirror any customs. For the most part, the customary engineering component had been overlooked and even disregarded. Contemporary design executes customary component; it could be coordinated to achieve the social congruity. Additionally, it could be guided to achieve atmosphere adjusted and practical design. The present contemporary engineering relies

ACE, 14. (42) CC BY-ND 3.0 ES | UPC Barcelona, España | Emerging Factors Shaping Identity Of Indigenous Urbanism Concurrently Adopting Modernity In Qatar: The Application Of Diffusion Theory. DOI: 
upon the mechanically controlled conditions, to achieve a safe place, and this will expand vitality (Antarikananda et al., 2006). Genuine social manageability will be accomplished through the mix of the nearby personality into urban improvement.

Ibrahim (2013) states that engineering in Qatar was worried about shielding the inside spaces from the serious character of the earth. The pattern was consulted in the old design. This is a result of utilizing nearby building materials and patterns that meet the earth (Ibrahim. 2013). The structures now are to work for last without hurting nature since Qatar turns into an open nation to the entire world; hence, Qatar started to rise as a worldwide center for media, instruction, culture, and fund through immense speculations and a few activities, for example, the Al Jazeera Channel, the Doha Economic Zone, the Education City, and Science and Community Development. Meanwhile, education and preparing of local planners are urgent aspects for overcoming any issues in the Gulf Region. In this sense, the late propelled graduate projects in urban planning and configuration in Qatar's national colleges, in addition, the expansion of urban-related professional grams in the UAE, Saudi Arabia, and other Gulf nations are to be respected as positive strides towards a more fit, organized, participatory, and more coordinated Gulf arranging framework (Rizzo, 2014). Ultimately, this development blast raised high rises, wear offices, gated groups, and notable exhibition halls. In this manner, in Qatar, contemporary engineering can be characterized as a blend of European, Asian, Islamic, Arabian, and nearby patterns.

\subsection{Islamic Architecture and Built Environment}

The meaning of what is an Islamic city, and whether an Islamic city had existed, are questionable subjects. For instance, Lapidus (1973) contended that the Arab Muslims did not settle only in new towns. Lapidus (1973) expressed that "the Arabs gave a specific catalyst to Middle East urbanization without causing a general increment in the level of urban advancement and without recognizing urban areas with Islam." Besides, Hamdan (1962) established this view expressing that towns in the Islamic period were an expansion of the prior ones and some of their morphological highlights were acquired, and others rose through the procedure of affiliation. The researchers, for example, Eikelman (1981) and Hakim (1985) see the Islamic city as a substance with unmistakable shape and qualities. A similar open deliberation has developed to incorporate the characterizing highlights and attributes of every single Islamic city or extraordinary to districts. Notwithstanding this civil argument, there is an understanding among researchers that the Islamic city has some run of the mill includes, as shown in the accompanying areas. Islamic architecture has specific components which shape its identity. The following presents these components, in detail.

i) The Mosque: The mosque plays the role of heart of the town. It is usually surrounded by the traditional market. The mosque holds the weekly Friday prayers and normally contained an attached school or college educating the public (Al-Sayyed,1991).

ii) Suqs and commercial districts: According to Al-Sayyed (1991), suqs were normally located around the main mosque, and were the hub of economic activity in the town. Furthermore, suqs played a major role in other public activities and gatherings such as trade, arts, and baths.

iii) Citadel: The citadel represented the palace of the governor. According to Al-Sayyed (1991), it was surrounded by its walls and included a district on its mosque, guards, offices, and residence. It was usually found in the high part of the town.

iv) Residential districts: Eikelman (1981) described the residential districts as a group of households based on personal relations. Residential quarters usually were dense and contained their mosque, school, and shops. In addition to that, they had their gates, which normally closed at night after last prayers and opened early each morning.

v) Networks: Networks consisted of narrow winding streets that included public, private, and semiprivate streets that connected residential quarters and the main places. Avenues and wide roads

ACE, 14 (42) CC BY-ND 3.0 ES | UPC Barcelona, España | Emerging Factors Shaping Identity Of Indigenous Urbanism Concurrently Adopting Modernity In Qatar: The Application Of Diffusion Theory. DOI: 
give the longest separation that makes a general island. Wide avenues and principle roads connect and sort out neighborhoods together. In expansive and medium urban communities, shops shape along with these rear ways and used for little social events.

vi) Wall: The walls around old Islamic urban communities have been the characterizing factors for some parts of the city including its physical points of confinement, resistances, and social and monetary stratification over a time of more than one thousand years.

vii) Exterior: Exterior is included the cemeteries that were segregated by the religious and weekly market just outside the main gate where most animal suqs were held in addition to private gardens and fields.

\section{Methods and Materials}

The research has conducted two phases, and each phase has a few steps. The following presents them in detail.

Phase one (1); It was to explore different urban zoning. It includes a detailed analysis of the different architectural styles and elements have spread the identity with regards to the main constituents of urban zones. Because of the difficulty to survey the whole Doha region, this research has focused on four (4) mega projects with different characteristics in Doha; included, Pearl Qatar (representing Islamic architecture), Souq Waqif (representing traditional architecture), Msheireb project (as the combination of traditional and modern architecture), and West Bay (as the reference for global approach). Phase one has conducted the following steps;

- Step One: Field Observation; It was to evaluate the characteristics of the built environment and contemporary architecture in four selected sites in Doha. The evaluation factors of field observation are; a general overview of the zones or districts of the project, defining the characteristics of the built environment, identifying landscape features and networks, looking at the overall impact of the spaces and atmosphere, and highlighting the architectural style and dominant feature.

- Step Two: Field survey, Based on the sampling size of ninety participants, the styles, barriers and resistancy, adoption of new styles and architectural elements of those selected sites were surveyed.

Phase two (2): It was to investigate the contemporary elements spread for built environment's identity with the concentration on the selected sites in Doha. The following steps have been conducted;

- Step Three: Photo survey, It lists all traditional architectural and urban elements, and finds out which of these elements appears in the contemporary built areas. To have the work systematically and objectively achieved, this survey is carried out the same ninety randomly selected participants with different ages, genders, occupations, and martial status. The characteristics of the surveyors (i.e., selected sample) are as follow. The research called the surveyors as 'adopters' because the diffusion theory calls the members of the society as adopters, as they adopt or go through the process of adopting new ideas. According to Figure 3a, among all age ranges, the age range 30-39 was the most occupied range (40\%). Figure 3b shows that 59\% of participants were female, and the rest were males (41\%). Figure $3 \mathrm{c}$ reveals that the occupation of adopters was 38\% professional, $28 \%$ student, and $10 \%$ academic. Also, Figure $3 d$ depicts that the marital status of the adopters was 59\% married and 32\% single.

ACE, 14 (42) CC BY-ND 3.0 ES | UPC Barcelona, España | Emerging Factors Shaping Identity Of Indigenous Urbanism Concurrently Adopting Modernity In Qatar: The Application Of Diffusion Theory. DOI $\underline{\text { http://dx.doi.org/10.5821/ace.14.42.8362 }}$ 
Figure 3. Surveyors (i.e., adopters) characteristics; a) Age groups of adopters, b) Gender of adopters, c) Occupation of adopters, d) Marital status of adopters

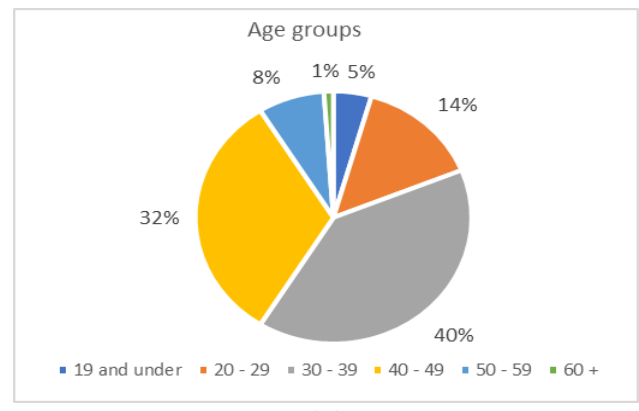

(a)

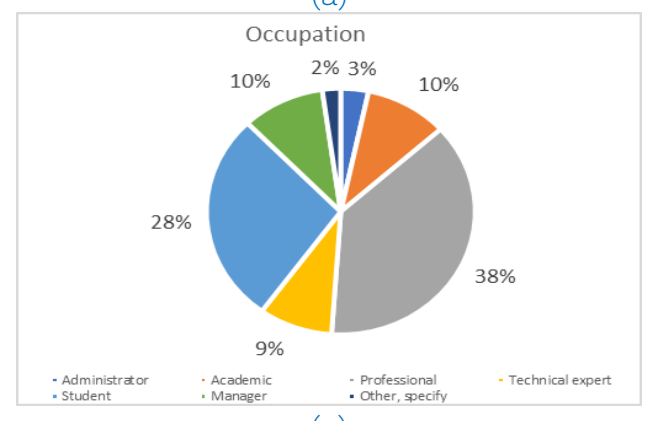

(c)

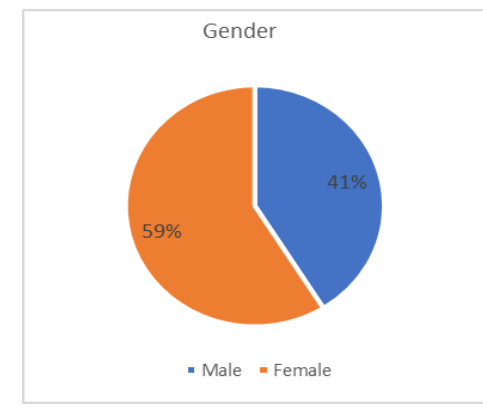

(b)

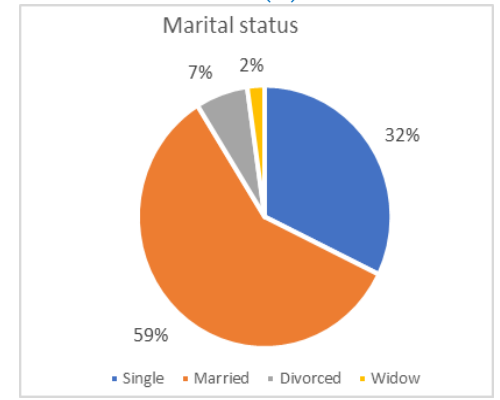

(d)

Source: Authors own elaboration.

In this regard, the research has surveyed to classify the eleven (11) images (i.e., photos) of different buildings to four classes of Qatari, Islamic, Modern, and other. The photos were selected based on the following factors, which are clustered into physical and non-physical aspects;

\section{Physical aspects of photo selection:}

a) Design Elements: The need for place identity leads to the creation of distinctive traditional design elements and their new application. Therefore, the focus of the research will be on static and dynamic elements that are the constituents of the identity of Qatari architecture and its contemporarily built environment.

a.1.) Static element/form are that element which preserves their original characters or associated meanings (For example, different proportions that have produced Roman, Seljuk, Ottoman, and Gothic forms).

a.2.) The dynamic element/form, is that element when it undergoes progressive changes, it is still resembling or recalling its original nature (For example, the Barjeel (i.e., wind catcher) keeps its nature even after the elimination of its details and decorative lines).

b) The application of Islamic geometrical pattern: It is applied in the skin of the Islamic study buildings (For example: in the Education City as a representation of the contemporary regional architecture).

Non-physical aspects of photo selection:

a) Place Identity: Lynch in 1981 defined it as "the extent to which a person can recognize or recall a place as being distinct from other places - as having a vivid, or unique, or at least a particular, character of its own" (Southworth and Ruggeri, 2010).

b) Doha Municipality: It is the major player in the proposition of city development and future strategies. The development of new urban areas is the process of conventional spatial analysis and application of architectural aspects that confirm the intended identity.

ACE, 14 (42) CC BY-ND 3.0 ES | UPC Barcelona, España | Emerging Factors Shaping Identity Of Indigenous Urbanism Concurrently Adopting Modernity In Qatar: The Application Of Diffusion Theory. DOI $\underline{\text { http://dx.doi.org/10.5821/ace.14.42.8362 }}$ 
First, people were asked to categorize eleven (11) photos representing Qatari, Islamic, Modern, and mixed architectural styles, as well as, other eight (8) photos of architectural elements. Second, participants were asked about the diffusion theory targeting their knowledge, interest, resistance, decision, implementation, and adoption of emerging ideas. The diffusion theory helps to explain the process of identity change of the local architecture in Qatar. Phenomenological changes in built environment start with the acquisition of information through a decision process that is better explained by the diffusion theory proposed by Torsten Hagerstrand (Lamit et al., 2013a; Lamit et al., 2013c) (see Figure 4). Gregory (1985) states there has been little advance in the architecture of diffusion theory in recent years. The change starts with the diffusion of information in an interactive matrix (general system of diffusion that refers to how the population in a regional system is structured) over the information field. "Diffusion is the spread of a phenomenon (including ideas, objects, and living beings) over space and through time" (Gregory, 1985 p160). In some aspect, it faces cultural barriers or resistance to change. Going over the resistances and barriers requires dynamic and adaptability or innovative changes (Baker, 2001). When the local architecture undergoes total changes, it faces an identity crisis. This occurs because the resistance of the spatial identity encounters a potential failure in the reproduction of systemic relations. Production of local architecture and reproduction of its identity, whether witnessing duplication or transformation in its form (static or dynamic) is a way of tracing identity resistance to change (Baker, 2001). In this case, an innovative solution could be the creation of a new form that resulted from melting traditional with new design ideas. In fact, the findings help in understanding how people perceive urban identity.

Figure 4. The structure of Hugerstrand's diffusion model

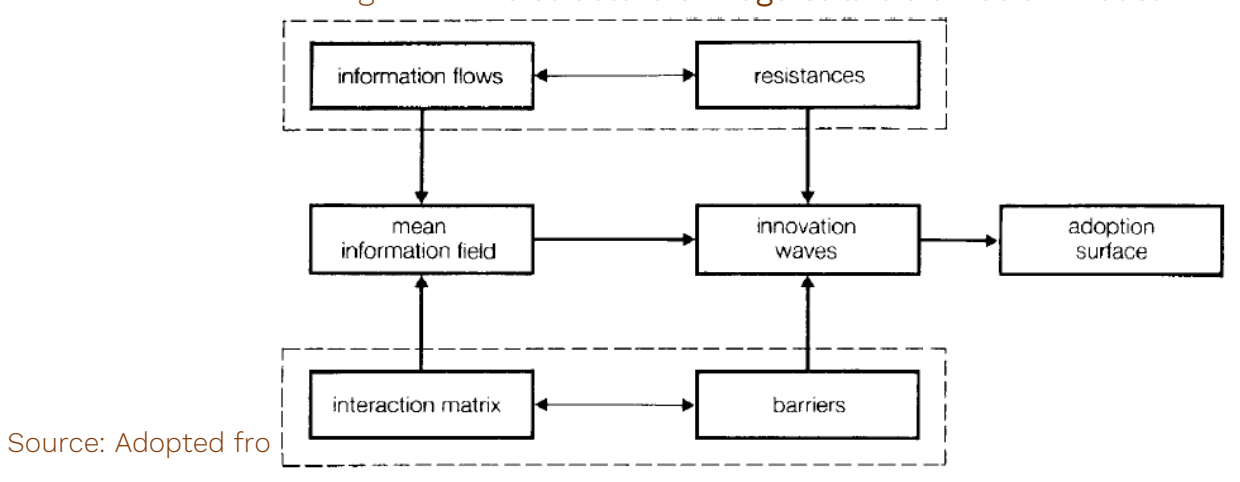

- Step Four-Interviews: The research has conducted the deep interview using phenomenology analysis method with two professionals: Chief Architect of the (AEB) Arab Engineering Bureau, and head of design and project director in Faim Design (FD) consultants.

\section{Analysis}

This section reports data analysis of phase one and phase two, respectively.

\subsection{Field Observation Analysis}

In phase one of the research, the four selected sites (i.e., Pearl Qatar, Souk Waqif, Msheireb, and West Bay) have been observed in detail. The observation was conducted across several factors; architecture features, site functions, built environment features, design style, zones configuration, urban design features, landscape features, and the overall impact. Table 1 presents the observation analysis of architecture and building design aspect, and Table 2 presents the urban design and built environment aspect.

ACE, 14 (42) CC BY-ND 3.0 ES | UPC Barcelona, España | Emerging Factors Shaping Identity Of Indigenous Urbanism Concurrently Adopting Modernity In Qatar: The Application Of Diffusion Theory. DOI http://dx.doi.org/10.5821/ace.14.42.8362 


\section{A) Architecture and Building Design Aspect:}

Field observations of the four selected sites show that in Pearl Qatar, the architectural trend is a contribution to the development of Arabian style architecture. The architecture in Pearl Qatar is reflecting the local identity in the sense that there is a regional impact in some of the zones, such as Porto Arabia. However, Qatari identity is not presented in this case as the existence of other global styles, and therefore, the environments create a major contradicting effect. The observation reveals that Souk Waqif is a unique historical landmark in Doha. It is an ancient local market that reflects the close trade and cultural exchange with southern Iranian borders and other Gulf countries. The architecture of Souk Waqif is typical of the northern part of the Arabian Peninsula that is deeply influenced by the southern architecture of Iran. In the observation, we understood Msheireb Downtown Doha is the world's first sustainable downtown regeneration project, designed to regenerate and preserve the historical heart of Doha. Msheireb blends traditional Qatari heritage and aesthetics with modern technology, focusing on sustainability and harmony with the environment. The project aims to bring people back to their roots - to make Doha unique and rediscover a sense of community and togetherness. Also, referring to the observations, West Bay zone is a coastline locale of the Qatari capital Doha where is now quickly forming into a focal business region. Since the late 1990s, many high rises have brought up in the locale. The locale was truly made in the mid-1980s after a gigantic land recovery venture along Doha's coastline and began to create in the mid-1990s.

Table 1. The field observations analysis of the cases from Architecture and Building Design Aspect

\begin{tabular}{|c|c|c|c|c|}
\hline Factors & $\begin{array}{l}\text { Case Study 3: } \\
\text { Msheireb }\end{array}$ & $\begin{array}{l}\text { Case Study 1: } \\
\text { Pearl Qatar }\end{array}$ & $\begin{array}{l}\text { Case Study 2: } \\
\text { Souk Waqif }\end{array}$ & $\begin{array}{l}\text { Case Study 4: } \\
\text { West Bay }\end{array}$ \\
\hline $\begin{array}{l}\text { Architecture } \\
\text { features }\end{array}$ & $\begin{array}{l}\text { The traditional and } \\
\text { modern approach of } \\
\text { plain facades with } \\
\text { modern screens } \\
\text { following traditional } \\
\text { aspects and themes. }\end{array}$ & $\begin{array}{l}\text { Western, Islamic. } \\
\text { Different facades, } \\
\text { colors, and } \\
\text { elements. } \\
\text { Recessions and } \\
\text { variety of openings } \\
\text { and arches. }\end{array}$ & $\begin{array}{l}\text { Traditional Qatari/ } \\
\text { Iranian. Stones, } \\
\text { recessions, wooden } \\
\text { roofs, and } \\
\text { rectangular } \\
\text { openings. }\end{array}$ & $\begin{array}{l}\text { Global with the } \\
\text { high tech of } \\
\text { glazed facades } \\
\text { and the use of } \\
\text { different } \\
\text { materials and } \\
\text { elements. }\end{array}$ \\
\hline Design Style & $\begin{array}{l}\text { Arabic, International, } \\
\text { Middle Eastern }\end{array}$ & $\begin{array}{l}\text { Arabic, } \\
\text { Mediterranean, and } \\
\text { European }\end{array}$ & $\begin{array}{l}\text { Arabian Peninsula, } \\
\text { Persian }\end{array}$ & International \\
\hline
\end{tabular}

Source: Authors own elaboration.

\section{B) Urban Design and Built Environment Aspect:}

Each site has specific urban and zone characteristics. The description of observation for each site is as follows;

Pearl Qatar; it is a human-made island spanning nearly four million square meters (see Figure 5a). The name "the Pearl" was chosen because the island is being built on one of Qatar's previous major pearl diving sites. Qatar was one of the major pearl traders of Asia before the Japanese introduced cheaper, more affordable pearls just before Qatar's oil boom. Residential development on the island is intended to incorporate various national and international themes, including aspects of Arabic, Mediterranean, and European culture. It has ten precincts with different styles and themes. Porto Arabia is a zone that consists of some Islamic architectural elements, openings, recessions, and wooden elements. The exterior of the buildings has a consistent harmony of shades that give a relaxing feeling and atmosphere for people (see Figure 5b). Medina Centrale is another zone that is located on a centralized position where the retail areas and internal car roads surround a central plaza. The central plaza consists of greenery, water fountains, and seating benches for the public ad paths for walking. Medina Centrale is unique in terms of colors, heights of the retail areas, roofs, and public spaces. The area is public and active during weekdays and weekends (see Figure 5c). Qanat Quartier is the other zone follows an Italian approach which characterizes the zone by a total global impact. Its built environment consists of water paths between high residential towers that are colorful. The contrasting effect of colors gives the zone a livable impact and a rich appearance. The

ACE, 14. (42) CC BY-ND 3.0 ES | UPC Barcelona, España | Emerging Factors Shaping Identity Of Indigenous Urbanism Concurrently Adopting Modernity In Qatar: The Application Of Diffusion Theory. DOI: 
zone is also rich by the architectural elements used like terraces, projecting prefabricated decorations of white gypsum and connecting bridges over the water paths (see Figure 5d).

Figure 5. Pearl Qatar urban characteristics; a) Pearl Qatar site plan, b) Porto Arabia zone, c) Medina Centrale zone, d) Qanat Quartier zone

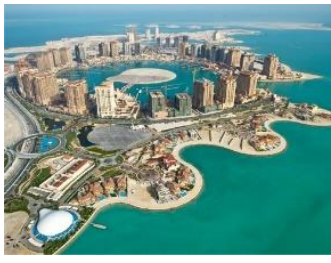

(a)

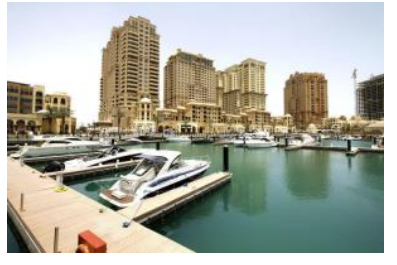

(b)

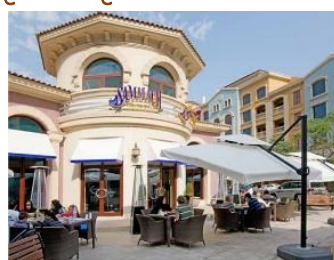

(c)

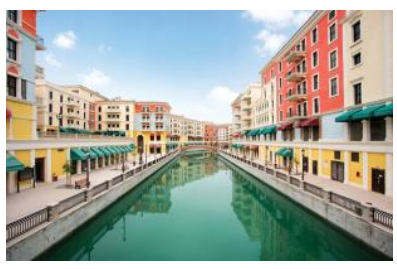

(d)

Sources: a) https://www.superyachts.com/marinas/viva-bahriya---the-pearl-qatar-2436/; b) https://www.arabianbusiness.com/-we-won-t-reverse-alcohol-ban-pearl-qatar-552748.html play2720.boloufduj57.agency/?utm_campaign=bKMuT7EMVXU5Z6UVvSHONGlfuyV43iC8T8uYixAFxs1\&t=main9_fe71274f255a069346fd; c)https://www.constructionweekonline.com/article30234-infrastructure-works-complete-at-the-pearl-qatar; d)https://mirageproperty.com/area-guide-qatarqanat-quartier-area/

Souk Waqif; it is one of the authentic historic points in the city of Doha. This shopping goal is outstanding for offering customary pieces of clothing, flavors, painstaking work, trinkets, fleece, adornments, and scents. Observing staying flimsy structures of an abused souk, the creator could revive the memory of the place through exceedingly masterful mediums and exhaustive field inquire about (see Figure 6a). The design of Souk Waqif is inspired by the northern part of the Arabian Peninsula that is profoundly affected by the southern engineering of Iran. The building framework connected comprises of dividers shaped with an arrangement of bearing fused sections with a traverse of $90 \mathrm{~cm}$. The holes between the columns are loaded with seashore stone making on the other hand windows and visually impaired curved put latticed boards for enhancing reason. The evident basic skeleton with the unpleasant covering is a key element of the considerable number of veneers around the souk. The shortage of the wood 'dangeel' made it consecrated to the level. This disposition is proof of the significance of wood as an uncommon material in the nearby condition (see Figure 6b). The outline idea in souk Waqif comprises of bringing back the memory of the place through restoration, redesign, or remaking activities (see Figure 6c). The task began as an arrangement of illustrations to persuade the Emir about the likelihood of restoring Souk Waqif. This demonstrates the accomplishment of the outline story locally and how the planner's ability lighted an entire enthusiasm of leaders on the wealth of their legacy (See Figure 6d).

Figure 6. Souq Waqif urban characteristics; a) the site map, b) Facades of some buildings, c) Interior view of the souk, d) legacy preservation of the site

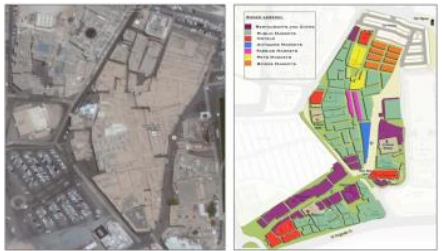

(a)

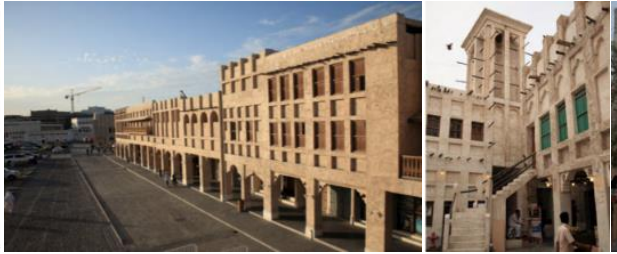

(b) (c)

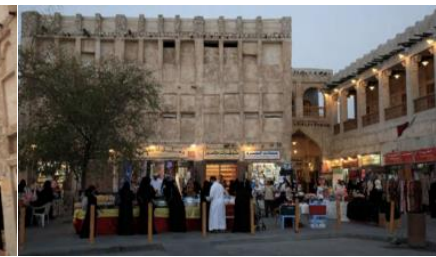

(d)

Sources: a) Furlan and Faggion (2015); b,c,d) https://www.akdn.org/architecture/project/souk-waqif

Msheireb; it is the world's first sustainable downtown regeneration project, designed to regenerate and preserve the historic heart of Doha. The Msheireb project blends traditional Qatari heritage and aesthetics with modern technology, focusing on sustainability and harmony with the environment. The project aims to bring people back to their roots - to make Doha unique and rediscover a sense

ACE, 14 (42) CC BY-ND 3.0 ES | UPC Barcelona, España | Emerging Factors Shaping Identity Of Indigenous Urbanism Concurrently Adopting Modernity In Qatar: The Application Of Diffusion Theory. DOI: 
of community and togetherness. One of the most important features of Msheireb is that it has preserved the original street pattern. The area was a closely packed district of low-rise (single-story) homes, with a complex network of small streets running through it. Built at a time before air conditioning was available, they were designed to resist the fierce Qatari heat. And with parking and services underground, there will be a sense of street life that had been lost dependency on the motor vehicle (see Figure 7a). While most of the preserved buildings are in the heritage quarter, a sense of history imbues the whole of Msheireb. It was achieved by maintaining the line of Al Kahraba Street (electricity street), an important historic street for Doha. While few may be alive to remember the street in its earliest incarnation, indeed, these historic links give cities texture and a sense of permanence (Figure 7b). The cluster of buildings, normally growing up around one important founding home, typically formed a neighborhood known as a fareej - a unique neighborhood identity where buildings complement each other in terms of scale, height, and bulk. Several characteristics define the traditional Qatari neighborhood. The courtyard, at the heart of the building, provides the outdoor space in a manner that is shaded and private, encouraging social interaction within the building (see Figure 7c). The public spaces are therefore highly outstanding with their form, contrasting with and complementing the other very important kind of space - the enclosed private space within the building (see Figure $7 d$ ).

Figure 7. Msheireb urban characteristics; a) site map zoning, b) Integration of traditional and modern style, b) Courtyard design of buildings, c) Configuration of inner and outer spaces of the building

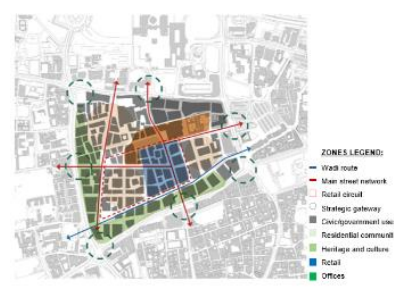

(a)

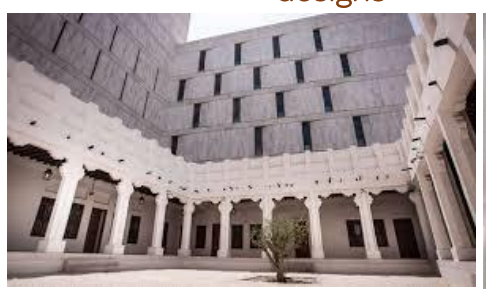

(b)

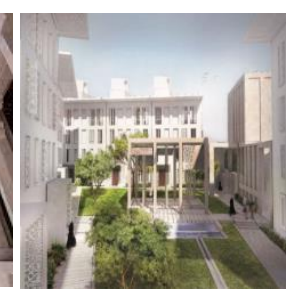

(c)

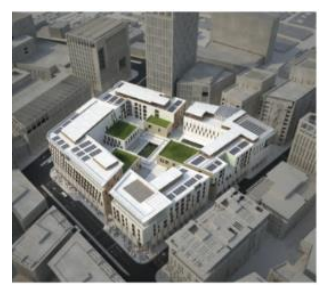

(d)

Sources: a) Msheireb properties, 2017; b) https://www.gulf-times.com/story/576818/Msheireb-Museums-in-RIBAs-list-of-best-new-buildi; c) https://www.pinterest.com/pin/448811919087928984/?lp=true; d) https://tr.pinterest.com/pin/466685580128554523/?lp=true

West Bay; it is quickly forming into a focal business region. Since the late 1990s, many high rises have brought up in the locale. Today, West Bay is quickly turning into Doha's new downtown area and with the monstrous measure of late improvement towards the north of Doha (Figure 8a). The general appearance of the West Bay range is worldwide. Nonetheless, a portion of the towers has a neighborhood effect regarding appearance, components, openings, and engineering. Different towers are post-current as they consolidate both present day and conventional like Barzan tower (Figure 8b). Likewise, Palm Tower is an image of the nation's social legacy. With glass box-like calculated projections down the sides of this hexagonal structure, the outline looks like the precise work of a palm tree, which is local to the district (Figure 8c). Conversely, the Tornado Tower has been touted for its special straightforward outline. The pinnacle decreases internal at the mid-point and after that outwards again at its most elevated point. In conclusion, on the extraordinary left of the horizon is the Al Bidda Tower. Worked in a turning design, like the Cayan Towers in Dubai, the adjusted triangular-formed base spirals in the center before leveling at the highest point of the pinnacle (Figure 8d). Scene segments in the greater part of the zone are not intended for people on foot. A few bistros and eateries exist in the ground floor of a portion of the towers that enable individuals or specialists to cross the streets and experience strolling in the territory amid their break hours. Qatar looks ahead to more noteworthy conceivable outcomes for the country, as the nation is attempting to mix current design with the nation's legacy and conventional feel. Creators are including embellishing components from the past in their intricate current structures.

ACE, 14 (42) CC BY-ND 3.0 ES | UPC Barcelona, España | Emerging Factors Shaping Identity Of Indigenous Urbanism Concurrently Adopting Modernity In Qatar: The Application Of Diffusion Theory. DOI: 
Figure 8. West Bay urban characteristics; a) site map zoning, b) Barzan tower, c) Palm tower, d)

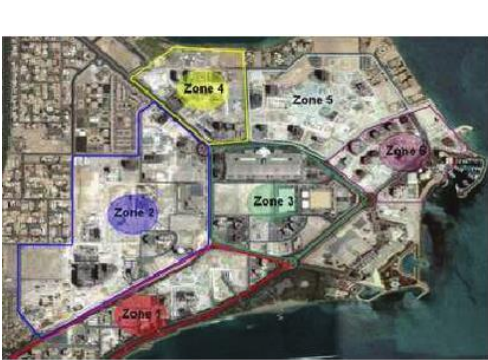

(a)

Tornado tower

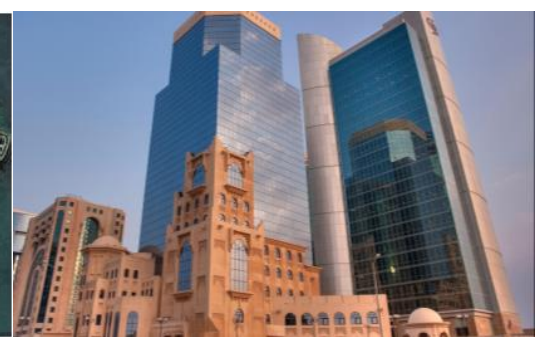

(b)

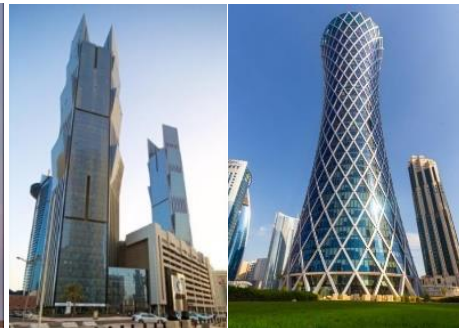

(c) (d)

Sources: a)Mahgoub and Abbara (2012); b)https://www.qatarliving.com/forum/qatari-culture/posts/spotlightode-barzan-tower; c)https://www.globalofficesearch.com/offices/Doha/majlis-al-taawan-west-bay-po-box26600-doha-23600/; d)http://joestravelguide.blogspot.com/

To sum up, the four sites are global that consists of some elements of Islamic architecture, traditional, mix between global and vernacular, and completely global architecture area. Table 2 presented a summary of sites observation regarding urban design and built environment characteristics.

Table 2. Field observations analysis of case studies, Urban Design and Built Environment aspect

\begin{tabular}{|c|c|c|c|c|}
\hline Factors & $\begin{array}{l}\text { Case Study 3: } \\
\text { Msheireb }\end{array}$ & $\begin{array}{l}\text { Case Study 1: } \\
\text { Pearl Qatar }\end{array}$ & $\begin{array}{l}\text { Case Study 2: } \\
\text { Souk Waqif }\end{array}$ & $\begin{array}{l}\text { Case Study 4: } \\
\text { West Bay }\end{array}$ \\
\hline Site Functions & $\begin{array}{l}\text { Historical and } \\
\text { Residential }\end{array}$ & $\begin{array}{l}\text { Commercial and } \\
\text { Residential }\end{array}$ & $\begin{array}{l}\text { Marketing and } \\
\text { Shopping }\end{array}$ & commercial \\
\hline $\begin{array}{l}\text { Built } \\
\text { environment } \\
\text { features }\end{array}$ & $\begin{array}{l}\text { Traditional urban } \\
\text { fabric with connected } \\
\text { networks and } \\
\text { traditional features. }\end{array}$ & $\begin{array}{l}\text { Global with highways } \\
\text { leading to each zone } \\
\text { and complicated } \\
\text { network. High raised } \\
\text { residential towers. }\end{array}$ & $\begin{array}{l}\text { Traditional with } \\
\text { low raise buildings } \\
\text { and narrow } \\
\text { pathways. }\end{array}$ & $\begin{array}{l}\text { Global with wide } \\
\text { public roads for } \\
\text { cars and high } \\
\text { raised commercial } \\
\text { towers. }\end{array}$ \\
\hline Design Style & $\begin{array}{l}\text { Arabic, International, } \\
\text { Middle Eastern }\end{array}$ & $\begin{array}{l}\text { Arabic, Mediterranean, } \\
\text { and European }\end{array}$ & $\begin{array}{l}\text { Arabian Peninsula, } \\
\text { Persian }\end{array}$ & International \\
\hline $\begin{array}{l}\text { Zones } \\
\text { configuration }\end{array}$ & $\begin{array}{l}\text { Connected four main } \\
\text { quarters. }\end{array}$ & $\begin{array}{l}\text { Ten precincts of the } \\
\text { human-made island. } \\
\text { Different scale of } \\
\text { zones and } \\
\text { configurations. }\end{array}$ & $\begin{array}{l}\text { Connected zones } \\
\text { of retail areas, } \\
\text { hotels, and public } \\
\text { plazas. }\end{array}$ & $\begin{array}{l}\text { Wide spread lands } \\
\text { for each tower/ } \\
\text { groups of towers. }\end{array}$ \\
\hline $\begin{array}{l}\text { Urban design } \\
\text { features }\end{array}$ & $\begin{array}{l}\text { Internal roads for cars. } \\
\text { Pedestrian pathways. }\end{array}$ & $\begin{array}{l}\text { Internal roads for } \\
\text { cars. Pedestrian } \\
\text { pathways within } \\
\text { zones. }\end{array}$ & $\begin{array}{l}\text { Paved pathways, } \\
\text { seating areas, } \\
\text { benches }\end{array}$ & Paved roads \\
\hline $\begin{array}{l}\text { Landscape } \\
\text { features }\end{array}$ & $\begin{array}{l}\text { Few greenery. Seating } \\
\text { areas and water } \\
\text { features, conventional } \\
\text { shutters }\end{array}$ & $\begin{array}{l}\text { Greenery and } \\
\text { different hardscape } \\
\text { and softscape. } \\
\text { Seating áreas, water } \\
\text { fountains, and } \\
\text { bridges, recessions. }\end{array}$ & $\begin{array}{l}\text { Few greenery on } \\
\text { planter boxes, } \\
\text { shopping stall. }\end{array}$ & $\begin{array}{l}\text { Few greenery and } \\
\text { seating areas or } \\
\text { means of } \\
\text { pedestrian } \\
\text { consideration. }\end{array}$ \\
\hline Overall impact & Traditional - Heritage & Global & Traditional & Global \\
\hline
\end{tabular}

Source: Authors own elaboration.

\subsection{Field Survey Analysis}

This step aimed to evaluate the selected sites in terms of local identity factors. The field survey has asked participants to rank the sites from 1 to 4 , where one is most presentative of local identity to 4 is the least presentative of local identity (see Figure 9). In Souq Waqif, there are many traditional functions and activities that reflect the traditional identity. The architectural impact and built environment of Souk Waqif reflect Qatar and the national identity highly. Msheireb has a unique local impact with the integration of modernity, while some traditional elements are used in a new language, while the overall impact of identity can be seen. Pearl Qatar has an Islamic and global impact. People

ACE, 14 (42) CC BY-ND 3.0 ES | UPC Barcelona, España | Emerging Factors Shaping Identity Of Indigenous Urbanism

Concurrently Adopting Modernity In Qatar: The Application Of Diffusion Theory. DOI: http://dx.doi.org/10.5821/ace.14.42.8362 
see a connection between Islamic and Qatari identity whcih can assign a higher rank to the site. West Bay is global, and the impact of Qatari identity can be obtained from new techniques and materials.

Figure 9. The field survey and ranking of the selected sites (i.e., Msheireb, Pearl Qatar Souk Waqif, and West Bay)

Source: Authors own elaboration.

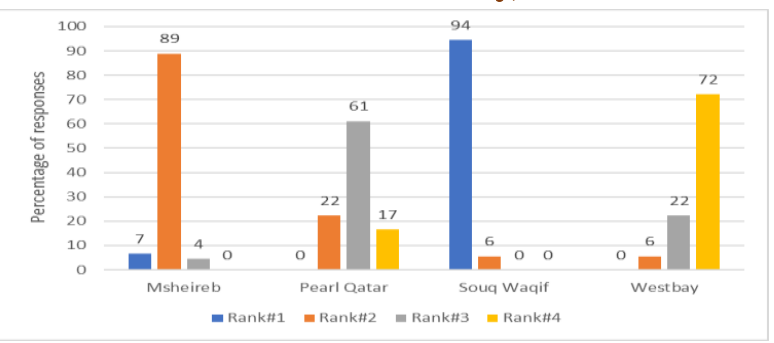

\subsection{Photo Survey Analysis}

As mentioned in step three of section 3. Methods and Materials, this research has conducted the Photo survey applying diffusion model on the adoption of global ideas and styles in evoking local identity. Referring to Figure 4, Diffusion model consists of few dimensions. So, the photo survey aims to understand how people's perception transfers from a basic information flow (i.e., traditional architecture's identity) to an adopted idea (i.e., contemporary architecture's identity). This section reports the data analysis of photo surveys in respect to each dimension of diffusion model as follow; A) People's perception on the interaction with built environment, B) People's perception on resisitancy of architectural elements, C) People's opinion about the changes in built environment's identity, D) Information flows and information fields of new ideas or emerging styles, E) Barriers and contributors to adopt the new architectural style, and F) People's awareness of the innovation waves in architecture and identity. The following presents the analysis of each dimension, respectively.

\section{A) People's perception of the interaction with the built environment:}

The aim was to understand how people conceive existing buildings in Doha as the relation between contemporary architecture and Qatari identity. In Souk Waqif, the survey has shown that the following images the highest ranks (see Figure 10). Barzan tower was ranked as 63\% Qatari and 37\% Islamic; Sharq village was ranked as 72\% Qatari and 28\% Islamic; and Mohammed Bin Abdul-Wahab mosque obtained the highest rank of 89\% Qatari, while 8\% Islamic and 3\% modern.

Figure 10. Left to right; Barzan tower, Sharq village, Mohammed Bin Abdulwahab mosque at the

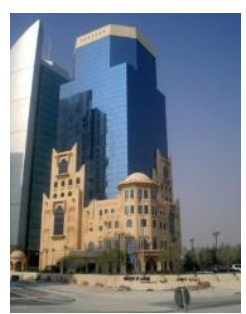
Souk Waqif site
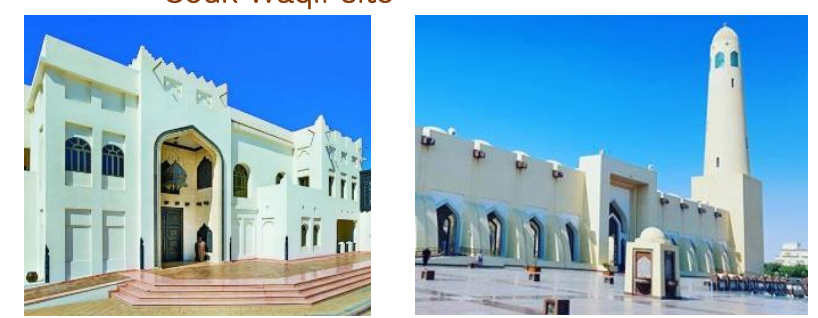

Sources: Left to right:

http://www.skyscrapercenter.com/doha/barzan-tower/15179

https://www.travelweekly.com/Hotels/Doha-Qatar/Sharq-Village-Spa-p3970129

https://deskgram.net/newindoha?next_id=1717185205603002570_5713725121

ACE, 14 (42) CC BY-ND 3.0 ES | UPC Barcelona, España | Emerging Factors Shaping Identity Of Indigenous Urbanism Concurrently Adopting Modernity In Qatar: The Application Of Diffusion Theory. DOI: $\underline{\text { http://dx.doi.org/10.5821/ace.14.42.8362 }}$ 
The images of the Msheireb project and the Museum of Modern Art in Qatar Foundation have also received the high ranks of being Qatari (see Figure 11). Msheireb's image has received the 58\% percentages for being Qatari, 29\% for modern and 8\% for others. Other responses for Msheireb's image was post-modern, with a definition of two participants; it is a combination of traditional and modern. The Museum of Modern Art was defined $77 \%$ as Qatari, $13 \%$ as Islamic, and $10 \%$ being modern.

Figure 11. Left to Right: Msheireb Project site, Museum of Modern Art at the Souk Waqif site
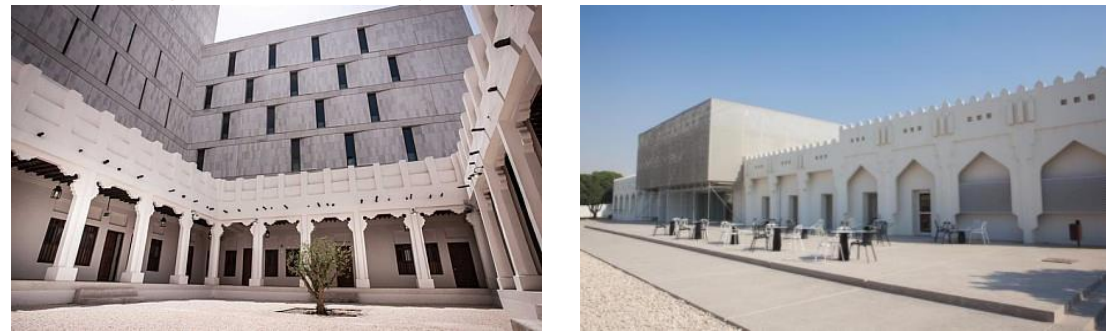

Sources: Left to Right: https://www.gulf-times.com/story/576818/Msheireb-Museums-in-RIBA-s-list-of-bestnew-buildi / https://www.astad.qa/sites/website/default/en/our-projects/all-projects/mathaf-arab-museum-ofmodern-art

Pearl Qatar was perceived as a mix between Qatari (39\%), Islamic (50\%), and modern (11\%). Pearl Qatar can be seen as modern and global in some of the zones that have been presented in the observation (such as Qanat Quartier) (see Figure 12). Pearl Qatar has mostly impacted an Islamic for using wooden screens in the facades. It is clear people confuse when it comes to making a clear comparison between Qatari and Islamic architecture. And finally, West Bay was defined as modern (86\%) and Islamic (13\%). The Islamic impact in West bay can be seen in some of the old towers that relied on using some Islamic elements, opening or materials like Barzan tower (see Figure 12).

Figure 12. Left to Right: Pearl Qatar site, West Bay site
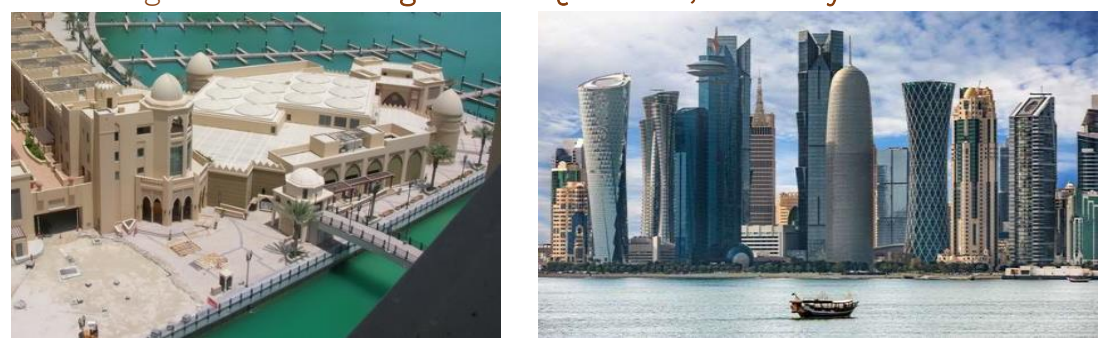

Sources: Left to Right:

https://www.superyachts.com/marinas/viva-bahriya---the-pearl-qatar-2436/

https://www.qatarads.qa/qatar-has-become-the-most-open-country-in-the-middle-east/

\section{B) People's perception of resisitancy of architectural elements}

This part of the survey aims to understand the people's perception regarding the elements attached to each style, and their shapes in the built environment. The six (6) architectural elements are shown in Figure 13. The first three images of Figure 13 show the selected elements of the wind catcher (or, Barjeel), the screen of an Islamic pattern, and an arch, respectively. In the survey, the wind catcher image was ranked as $82 \%$ Qatari and 16\% Islamic. The wind catcher is a regional element, commonly seen in the Gulf region. In Qatar, the wind catchers are seen in Souq Waqif and other buildings in different forms or shapes. The screen of an Islamic pattern was ranked as $85 \%$ Islamic. The use of such a pattern is rare in Qatar, while the other patterns are being mostly used to represent the country's culture. The arch was ranked as 75\% Islamic, and 25\% for being Qatari. The use of arches is seen in various forms and geometries in Qatar. The image of the arch shows a pointed arch, and maybe that is why people could not classify it as Qatari. The other three images of Figure 13 show

ACE, 14 (42) CC BY-ND 3.0 ES | UPC Barcelona, España | Emerging Factors Shaping Identity Of Indigenous Urbanism Concurrently Adopting Modernity In Qatar: The Application Of Diffusion Theory. DOI: 
the Mashrabiya, Qatari wooden traditional ceiling, and a modern metal screen of Doha tower. The Mashrabiya was classified as 98\% Islamic. Mashrabiyas, in this form, is rarely used in Qatar. Such Mashrabiyas are commonly seen in Egypt. The Qatari wooden traditional ceiling was classified as $96 \%$ Qatari. Such a technique is highly used in Qatar and widely spread in Souk Waqif, which defines it as a Qatari element. The modern metal screen was classified as $71 \%$ Islamic while $29 \%$ for being modern.

Figure 13. The selected elements for the assessment

(1.Barjeel/wind catcher, 2.Screen with Islamic pattern, 3.Pointed arch, 4.Mashrabiya, 5.The traditional wooden roof, 6 . Modern Islamic pattern)

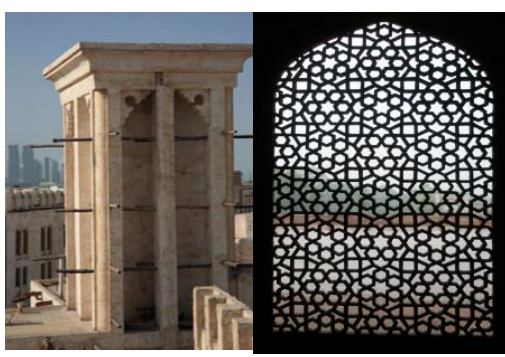

1

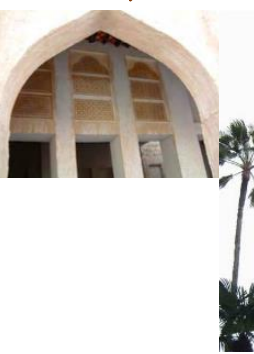

3

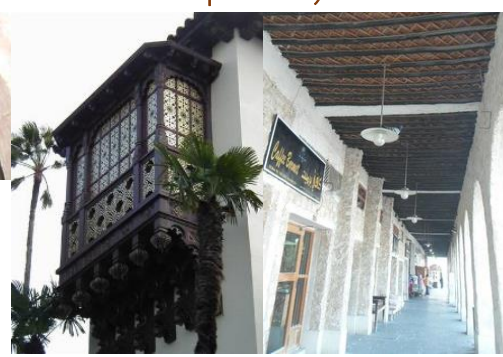

4

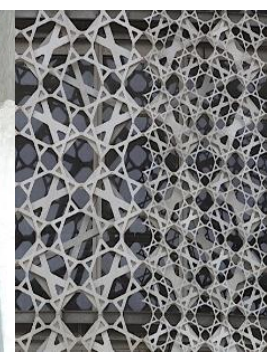

6

Source: Authors own elaboration.

C) People's opinion about changes in the built environment's identity:

This part of the survey has aimed to get the respondents' opinion about the built environment identity they experience through the architecture styles surrounding them. The first question targeted exploring if respondents think that "the identity of Qatar survives from the encroachment of the contemporary architecture," which 35\% of respondents agreed on this statement. The majority disagreed showing that Qatari identity is not seen in current contemporary architecture. The second statement was, "Contemporary architecture in Qatar is a mixture of styles and does not present Qatar," which 74\% of respondents agreed. The third statement was "Qatari architecture undergoes an identity crisis," and most of the respondents agreed (67\%).

D) Information flows and information fields of the new ideas or emerging style:

The research has surveyed with the aim of understanding which field or sector has been mostly influenced by new architectural ideas or emerging style. Refereeing to Figure 14, participants believe that the commercial sector was highly influenced by modern architecture. New commercial buildings (especially shopping malls) follow modern design trends. Institutions (like Banks) follow the modern design trend of glazed facades, aluminum, and skylights. Also, the residential sector has been influenced where people started to move towards high-rise residential towers. Surprisingly, the religious buildings are not influenced by architectural modernity and modern design.

Figure 14. The sectors are influenced by new architectural ideas and style

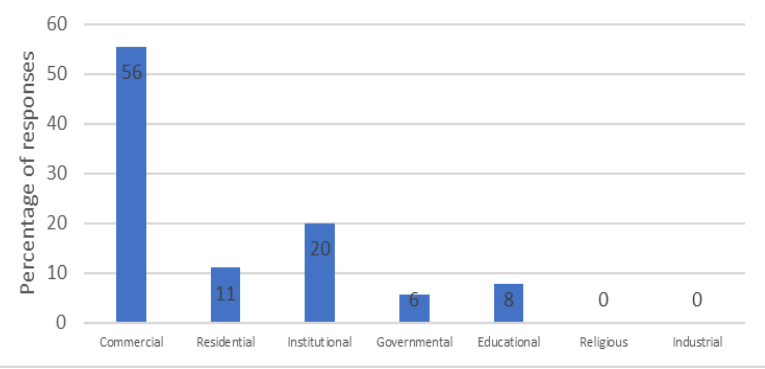

Source: Authors own elaboration.

ACE, 14 (42) CC BY-ND 3.0 ES | UPC Barcelona, España | Emerging Factors Shaping Identity Of Indigenous Urbanism Concurrently Adopting Modernity In Qatar: The Application Of Diffusion Theory. DOI: $\underline{\text { http://dx.doi.org/10.5821/ace.14.42.8362 }}$ 


\section{E) Barriers and contributors to adopt the new architectural style}

The research has surveyed to identify which factors act as barriers in the process of adopting a new architectural style/trend that might influence the current built environment. This part of the survey consists of two questions. The first question was to outline the factors that resist the changes. Referring to Figure 15, the responses show that building regulations and climate act as the main barriers. The building regulations might act as obstacles in some of the cases. Some exceptions should be made in some of the new architectural styles where the cases allow local architects to explore new techniques or the use of new materials. Besides, the climate acts as a barrier in terms of using a certain material or technique that does not suit the regional climate of the Gulf.

Figure 15. Overall assessment of the factors resist adoption to the new architectural style

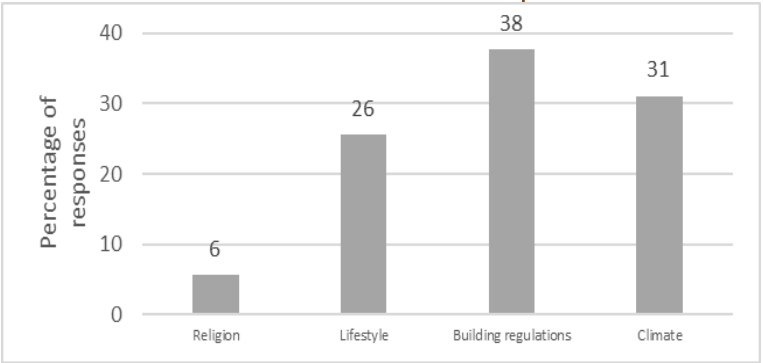

Source: Authors own elaboration.

The second question targeted viewing the other side of the argument, and the factors help to carry the new architectural changes. Respondents were asked to mark the factors they believe have the greater impact of adopting changes to their built environment and architecture. Referring to Figure 16, the lack of knowledge was ranked as the highest contributing factor. Qatari heritage should be spread among professionals and the public. Qatari heritage should be translated into means of practice and techniques that professionals can apply in future projects and urban developments. Globalization was ranked as the second factor that helps in adopting a new style or idea in society. Qatar has a mixed population of many different nationalities. It is a fact that some thoughts and ideas have emerged to society through different ethnic groups. Ideas that have influenced the planning process and governmental decisions came from international ideas and standards. International standards emerged to local organizations and influenced decisions made on planning and future developments in the country. Prestigious could be seen in many forms of challenging forms and using new techniques or building materials. Other prestigious forms are seen in private residences and properties where owners follow a classical Roman style or other global styles in their residences.

Figure 16. Overall percentages of factors contribute to adoption to the new architectural style

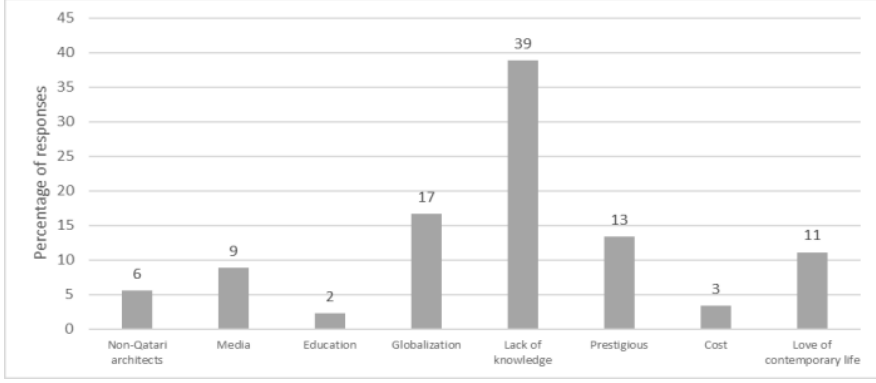

Source: Authors own elaboration.

F) People's awareness of the innovation waves in architecture and identity

The last part of the survey aimed to evaluate people's awareness of the association between architecture and identity. Buildings around us shape the built environment. Other landscape elements

ACE, 14 (42) CC BY-ND 3.0 ES | UPC Barcelona, España | Emerging Factors Shaping Identity Of Indigenous Urbanism Concurrently Adopting Modernity In Qatar: The Application Of Diffusion Theory. DOI: 17 http://dx.doi.org/10.5821/ace.14.42.8362 
and approaches help to conceive the impact of architect or designer to deliver to the public. The participants were asked to express their opinion on ten statements. The weighted scores of each statement. $70 \%$ of respondents strongly disagreed that "Qatari architecture has a strong connection with history." 36\% strongly agreed with the statement that "I am aware of the existence of traditional Qatari architecture." Almost 55\% strongly agreed that "Qatari historical buildings have a unique style." $72 \%$ of respondent strongly agreed, "New developments and architectural designs should follow the style of Qatari local architecture." 65\% strongly agreed that "combining modern and traditional is a good way to retrieve the identity of Qatari architecture." $75 \%$ of respondents strongly agreed that "modern architecture presents prestigious development." 80\% of respondents strongly agreed, "Qatar has many modern and iconic buildings that are as important as the traditional buildings." $94 \%$ of respondents strongly agreed that "Decision makers should pay more attention to the identity of Doha's future image." 60\% strongly agreed that "Architectural identity should be related only to traditional style." And, 86\% strongly agreed, "Qatar is witnessing changes in local architecture and urban layout."

\subsection{Phenomenology Analysis of Interviews}

In phase two, the research has conducted a deep interview with two experts who had extensive knowledge of Qatari architecture and urban development. The following presents the output of the interview analysis;

First interview: The director of the Arab Engineering Bureau (AEB) was one of the interviewees. He is a pioneer of a new architectural movement which combines the far-reaching influences of Islamic art with modern style, creating memorable landmark structures that are helping to shape the developing state of Qatar. He stated that "It was a great thing for the government to have preserved Souq Waqif [as a traditional architecture], although, admittedly, large parts of it were reconstructed. Still, among the structures are some beautiful original heritage buildings". On a wider scope, there are several forts within Qatar which have been preserved (Ibrahim, 2013). Also, there are some interesting mosques scattered around the country; those mosques were preserved, and now they are being renovated as authentic examples of heritage buildings (Ibrahim, 2013). He also expressed that all of these old structures serve as standing documents of Qatar's heritage. From his perspective, this is the combination of what created the Gulf identity. He believes the identity is extremely unique in Qatar and is limited to the shores of the Gulf. While there is a general classification under which many of these buildings fall, there are also subtle distinctions. He expressed that "There is a slight variety from one town to another that makes each unique. You tend to see more wind towers in the old Dubai, for instance, and Qatar was never really known for wind towers. As you get deeper into the heart of the Arabian Peninsula, you see more of a fortress type of architecture. As you come closer to the shores, the architecture changes with more arcades and open spaces rather than fortresses. If you look closer, you will realize there is a uniqueness to every single village, depending on such factors as the builders, the style, the building materials available and even the environmental topography".

Second interview: We have interviewed with the head of design and director in FD consultants. She has more than ten years of experience. She has raised the issue of distinguishing between local architecture and Local urbanism. She believes that in Qatar, the decision makers are trying to preserve the local architecture; however, unfortunately, they cannot perform the same in urban design and development. Regarding the influence of modernity on governmental, mosques and residential sectors, she added that the buildings' regulation in Qatar is obtained approvals from PEO (Private Engineering Office) on the facades of all Governmental buildings (including the local educational buildings). And, some residential areas such as Al Qutaifiya lagoon has some restrictions in the design of the facades, all should be designed with inspiriting of local architecture and with using all traditional

ACE, 14 (42) CC BY-ND 3.0 ES | UPC Barcelona, España | Emerging Factors Shaping Identity Of Indigenous Urbanism Concurrently Adopting Modernity In Qatar: The Application Of Diffusion Theory. DOI 
vernaculars accordingly. She expressed that there is a control on the architecture design, and there are some obligations on the architectural firms to keep the designs integrated with the context and the local architecture. Although the building regulation in Qatar is playing the main role to preserve the identity of the local architecture, integration with the surrounding, accessibility and understanding the local urban fabric need to be researched (Dalal, 2017). Moreover, the relationship between the architecture and the local urbanism is the most dialectic subject in surviving the identity (Dalal, 2017).

\section{Results and Findings}

Field observation resulted that it is clear some people relate Qatari architecture to Islamic while consider some architectural elements as common. People confuse when it comes to making a clear comparison between Qatari and Islamic architecture. However, people understand the mix between traditional and modern design. Some of them can define that and others relate it to modernity as a new approach or style which combines both. Qatari identity is not seen in today's contemporary architecture. The respondents think that contemporary architecture is a mixture of styles and does not present Qatari architecture. The majority of the samples shows disagreement about the connection of contemporary architecture with the local Qatari identity. Identity crisis refers to a total loss of identity. The statement might not be the best to explain the case as Qatar faces some cultural resistance that stands against the total change or crisis. The response shows that surveyors believe the commercial sector was highly influenced by modern architecture. New commercial buildings follow modern trends, especially shopping malls. Institutions like banks follow the same trend of glazed facades, aluminum, and skylights, and the residential sector has been influenced by modernity as well.

The response reveals that Qatari architecture has a stronger connection with the Gulf region. Many elements are shared within Gulf countries, and accordingly, it can be defined as regional architecture and not Islamic (see Figure 17). From this evaluation, it could be concluded that people perceived the mixture of traditional and modern architectures. Figure 18 shows the percentages of responses on the architectural styles of each eleven photos. The respondents have ranked the sites as; 1 . Souk Waqif, 2. Msheireb, 3. Pearl Qatar, and 4. West Bay. In Souk Waqif, there are many traditional functions and activities that reflect the traditional identity. The architectural impact and built environment of Souk Waqif reflect extremely Qatari and the national identity. Then, respondents preferred the approach followed in the Msheireb project, which was followed by Pearl Qatar. Msheireb has a unique local impact on the integration of modernity. Some traditional elements are used in a new language, but the overall impact of identity can be seen. Pearl Qatar has an Islamic and global impact.

Figure 17. Overall assessment of the six selected elements

(Notes: 1. Wind catcher, 2. Screen with Islamic pattern, 3. The pointed arch, 4. Mashrabiya, 5. The traditional wooden roof, 6 . Modern Islamic pattern)

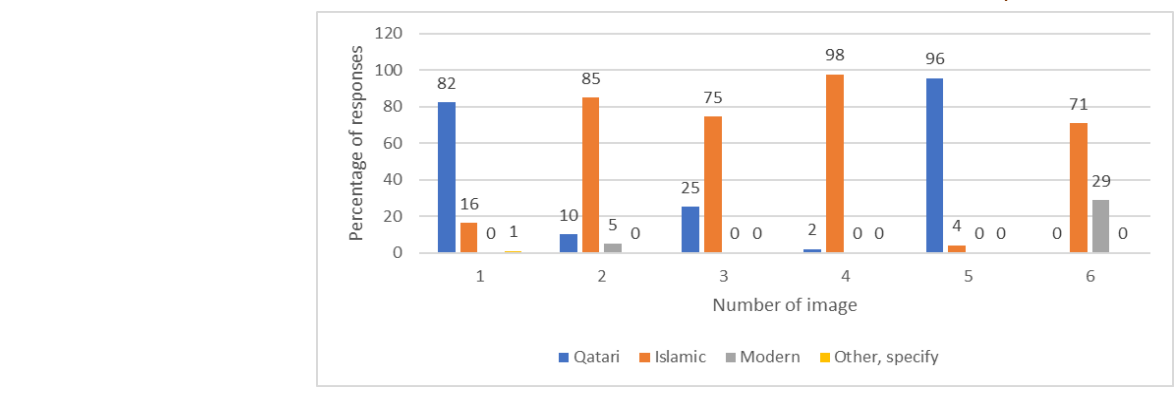

Source: Authors own elaboration.

ACE, 14 (42) CC BY-ND 3.0 ES | UPC Barcelona, España | Emerging Factors Shaping Identity Of Indigenous Urbanism Concurrently Adopting Modernity In Qatar: The Application Of Diffusion Theory. DOI: $\underline{\text { http://dx.doi.org/10.5821/ace.14.42.8362 }}$ 
Figure 18. Overall assessment of the eleven selected images regarding architectural styles and elements

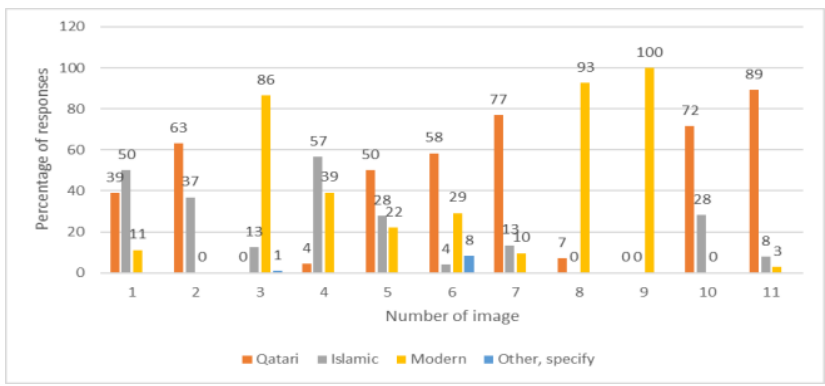

Source: Authors own elaboration. Notes: 1. Pearl Qatar, 2. Pearl Qatar, 3. Pearl Qatar, 4. Museum of Islamic art, 5. Qatar university- main building, 6. Msheireb project, 7. Museum of modern art, 8. The National Museum, 9. Radisson Blu hotel, 10. Sharq village, 11. Mohammed Bin Abdul-Wahab mosque

Furthermore, the responses show that respondents do not see a connection between current architecture and the history of Qatar. People are aware of Qatari architecture, and more awareness should be spread, and more means of education should be available for the public. Resources on Qatari traditional or vernacular architecture might not be available or easily accessed for some people. More awareness should be spread, and more means of education should be available for the public. Uniqueness is one of the aspects that highlight Qatari vernacular architecture, and this uniqueness should be maintained in contemporary building designs. Qatari people wish to see more buildings that reflect Qatari heritage. A mixture of styles is a new contemporary approach that has been followed in several examples in Qatar; such as, the national museum, the museum of modern art, Barzan tower, and Msheireb project.

\section{Discussions}

Every settlement with its exceptional qualities must create a particular arrangement and control to manage the issues postured by the discontinuity of the urban texture. These should address two main range of concerns. Firstly, everything except the most current settlements, contain a center of conventional structures. The center must be protected and re-established, and slowly be coordinated into a bigger and more sound group. Second, with a couple of exemptions, every one of the settlements in the area has acquired a cutting edge urban texture which must be changed and indigenized if the urban communities are to produce their uncommon type of current life. At the nearby level, a lucid general arrangement for urban development ought to be embraced. The destinations of this arrangement should spare to lessen financial and social disparities and clashes; gather the different pieces of the city into a bound together entire; control and deal with the physical development of the city while mulling over the country and provincial financial and natural approaches. The urban strategy must align not just with the physical contemplations of development (e.g., urban condition, transportation, dissemination, urban plan framework), with different regions of extraordinary concern (for example, work, social administrations, lodging, pay uniformity and social equity). There are incredible threats intrinsic in concentrating upon the physical and engineering contemplations of urban improvement without dealing with the financial, social, and political needs of the general population themselves.

This research has correlated the physical and nonphysical aspects of the built environment's identity. The research has highlighted the built environment identity, which is often neglected or oversimplified by architects and designers. The focus of this study was on static and dynamic elements that are the

ACE, 14 (42) CC BY-ND 3.0 ES I UPC Barcelona, España | Emerging Factors Shaping Identity Of Indigenous Urbanism 20 Concurrently Adopting Modernity In Qatar: The Application Of Diffusion Theory. DOI: http://dx.doi.org/10.5821/ace.14.42.8362 
constituents of the identity of Qatari architecture and its contemporarily built environment. Static elements which preserve their original characters or associated meanings and any change in their details and dimension lead to the loss of their original image. For example, drawing an arc with different proportions produces Roman, Seljuk, Ottoman, or Gothic forms. Accordingly, any arbitrary change in the proportion of any of these historical arcs will vanish its originality. On the other hand, the dynamic element is that element when it undergoes progressive changes; it is still resembling or recalling its original image. For example, the wind catcher (or, Barjeel) keeps its character even after the elimination of its details and decorative lines.

Furthermore, this research has highlighted the aspects of diffusion theory (diffusion theory and transition of ideas) and how it relates to the information flow of new ideas and factors that shape the current built environment. In particular, the research has asked the surveyors the questions related to the diffusion theory targeting their knowledge, interest, resistance, decision, implementation, and adoption of emerging ideas. The findings help in understanding how people perceive the present urban identity and its emerging factors. The research indicates the degree of domination of different styles. The research shows that Doha is the mean information field over which the implication of new design innovation is spread. Doha's architecture and built environment respect to the cultural constraints and physical boundary that are playing significant roles in shaping the city.

Camillo Sitte states that our townscape has been irrevocably changed; square deprived of being a social space, but it becomes roundabout (Larice and Macdonald, 2007). That creates a chaotic pattern in the city. Sentimentality was the motive for the production of urban space and artistic motifs, now logical relationship among elements and functional requirements have taken place (Larice and Macdonald, 2007; Ferwati et al., 2019). There are many examples where elements such as city growth, road flow, and entrance noticeability have taken many forms and evolved to meet new movements and social expression. While the application of other elements (whether urban or architectural) such as water fountains, light fixtures, lattice windows, arcs, etc. stand in the public place for functionalism. Venture and Scott Brown (1974) has criticized architectural functionalism. On the meaning of 'Architecture,' Venturi et al. (1977), in their book 'Learning From Las Vegas' have developed the equation of 'Firmness + Commodity + Delight' that presents functionalism. The functionalism is "a departure from the discipline's most venerable theoretical foundation” (Venturi et al., 1977, p. 10). Venturi et al. (1977) express that 'Structure + Program' produces 'Form' (although, beauty is a byproduct); it means that by producing architecture its process becomes the image of architecture, and so, the 'Delight' will result from the harmony and clarity of this relationship (which is untinged by the beauty of ornament and symbolism or form). The symbolism of form (and its embedded arts) can reinforce and express the content of architectural space through physiognomic characteristics and the inherent of the form (Venturi, 1974; Venturi, 1966). Also, Venturi et al. (1977) state that contemporary architecture combines the tradition of iconology in which hardscape (fountain, sculpture, etc.) can bind with softscape (trees, flora, and fauna, etc.). Venturi et al. (1977, p.9) state that "the integration of the arts in modem architecture has always been called a good thing." For example, the illusionistic frescoes in a Venetian villa, Las Vegas, contain messages beyond the ornamental contribution to architectural space.

The distinctive local architecture of Qatar is responsible for the identity of the built environment. The misuse of traditional and contemporary elements is manifested in many ways. For example, the application of the Roman Arc as an Islamic element, or the Islamic geometrical pattern applied in the skin of a building in the Qatar Education City is a representative of the contemporary regional architecture. Misusing architectural elements and their symbolic meanings has become an intensive problem resulted from the unawareness of the designers in applying Qatari regional and international architectures. The unawareness might come from a lack of knowledge or experience. The resulting is fading away from the local spatial identity. Fading away, the place identity is blamed upon the short

ACE, 14 (42) CC BY-ND 3.0 ES | UPC Barcelona, España | Emerging Factors Shaping Identity Of Indigenous Urbanism Concurrently Adopting Modernity In Qatar: The Application Of Diffusion Theory. DOI: 21 $\underline{\text { http://dx.doi.org/10.5821/ace.14.42.8362 }}$ 
outcome of the adequate studies that link traditional architecture with inevitably-dominating contemporary architectural style. Hence, the research itself is important for increasing the understanding of Qatari urban architecture and cultural heritage, for the benefit of scholars, urban planners, as well as citizens.

Moreover, the benefit of this research targets Doha Municipality, the major player in the proposition of city development and future strategies. The development of new urban areas is the process of conventional spatial analysis and application of architectural aspects that confirm the intended identity. Therefore, this research highlights profound urban and architectural problems such as the neglected value of traditional architectural style and poor application of local style within the international designs. The implementation of this study highlights the continuous need to understand the static concept and the dynamic architectural form that can be applied both for building conservation, reconstruction and even for new sites development. Regarding traditional Islamic city, we can conclude the absence of any connection between the old Islamic design principles and the characteristics of the modern Islamic cities now. This may be the main reason behind the economic, social, and identity crisis of the urban communities in modern Islamic cities. There is a need to apply the principles of traditional Islamic cities to bring our cities back to the livability of the Islamic life.

\section{Conclusion}

It was a response to growing wealth and knowledge at a time when there was relatively little understanding of either the preciousness of natural resources or the importance of community. Qatar has an opportunity to move on from that point in a way that is typically Qatari by embracing the best of its traditional architecture and consciously enjoying a sense of community. The new architecture should embrace the past while providing improved space standards, amenities, and services that are available and desirable in the 21st Century. In this regard, this study concludes that;

- It is only through a full understanding of the past, and the strengths of vernacular architecture that one can develop an architecture for today that is appropriate to the climatic conditions and culture.

- Traditional buildings provide clues for creating successful contemporary streets. The building frontages touch each other, and all follow a connected building line. Even in a modern suburb, where buildings will be set back from the street, boundary walls can perform this function, together with the alignment and common orientation of building fronts.

- A successful city area balances the needs of the individual with the needs of society and the desire for interaction. The way that these works will be determined by history and culture, and design can best accommodate these by drawing on and reinterpreting tradition.

- $\quad$ The characteristics of space and form that are typical of the Gulf region are the existence of low-rise buildings that are in clusters and largely asymmetric. There is a contrast between the formality of major buildings and the informality of everyday buildings. Buildings about the street line, with private space and decoration contained inside, and public space is carved out from this solid mass of buildings. Following this approach is a key part of the new architectural language. This will create a form of city that is familiar and well-suited to the Gulf region and its culture.

- City quarters work best when they balance the individual and the collective in both the physical and the social sense. In the Gulf, where the tradition was to build in clusters rather than single buildings, there was a good foundation for this can be emulated today, treating buildings as part of the larger city fabric. This reflects the social structure of the city as well as being aesthetically pleasing.

ACE, 14 (42) CC BY-ND 3.0 ES | UPC Barcelona, España | Emerging Factors Shaping Identity Of Indigenous Urbanism Concurrently Adopting Modernity In Qatar: The Application Of Diffusion Theory. DOI http://dx.doi.org/10.5821/ace.14.42.8362 


\section{Acknowledgement}

The authors would like to express their gratitude to interviewees, Ibrahim Al-Jaidah (chief architect in Arab Engineering Bureau (AEB)), and Dalal Harb (head of design and project director in FD consultants), for their valuable contributions to this research.

\section{Authorship}

All the authors have contributed significantly to the manuscript preparation. Dr. M. Salim Ferwati has initiated the concept of the research. Dr. M. Salim Ferwati has initiated the conceptual design of this research. Dr. M. Salim Ferwati, Rana Salman Wadi, and Omar Ferwati, have conducted the fundamental study and literature review of the manuscript; in parallel, Dr. Arezou Shafaghat, Dr. Ali Keyvanfar, and Omar Ferwati have contributed to the research methodology and data analysis of the manuscript, and also, rounds of review and editions.

Conflict of interests: The authors declare that there is no conflict of interest.

\section{Bibliography}

Al-Sayyad, N. Cities and Caliphs: On the Genesis of Arab Muslim Urbanism (Critical Responses in Arts and Letters) 1st Edition. Greenwood Press, Westport, USA. 1999. 196 p.

Antarikananda, P., Douvlou, E., \& McCartney, K. Lessons from traditional architecture: Design for a climatic responsive contemporary house in Thailand. In Proceedings of the PLEA2006 23rd Conference on Passive and Low Energy Architecture, Geneva, Switzerland (pp. 6-8). 2006.

Baker, L. A. Static and Dynamic Characterization. 2001 [Access data: 20 July 2017] Available at: <https://www.k-state.edu/english/baker/english320/cc-static_vs_dynamic_characterization.htm>

Chavoya Gama, J. I. Public Space and Identity In The Coastal Tourist City, Puerto Vallarta-Bay Of Banderas, Mexico Case. In: Ace-Architecture City and Environment. [on line]. 2016, vol. 11, issue 31, pages: 177-190. [Access data: 4 July 2019]. Available at: < https://revistes.upc.edu/index.php/ACE/article/view/4658/397

Eikelman, D. The Middle East. An Anthropological Approach. Prentice Hall, Englewood Cliff, New Jersey, USA, 1981. $176 \mathrm{p}$.

Erickson, B. and Roberts, M. Marketing local identity. In: Journal of Urban Design. 2(1), 35-59, 1997.

Furlan, R. Urban Design and Livability: The Regeneration of the Corniche in Doha. In: American Journal of Environmental Engineering. 6(3), 73-87, 2016.

Ferwati, M. S., Al Saeed, M., Shafaghat, A., \& Keyvanfar, A. Qatar Sustainability Assessment System (QSAS)-Neighborhood Development (ND) assessment model: coupling green urban planning and green building design. Journal of Building Engineering, 22, 171-180, 2019.

Furlan, R. and A. Petruccioli. Affordable Housing for Middle Income Expats in Qatar: Strategies for Implementing Livability and Urban Form. In: International Journal of Architectural Research-ArchNetIJAR. 10(3), 138-151, 2016.

ACE, 14 (42) CC BY-ND 3.0 ES | UPC Barcelona, España | Emerging Factors Shaping Identity Of Indigenous Urbanism

Concurrently Adopting Modernity In Qatar: The Application Of Diffusion Theory. DOI: $\underline{\text { http://dx.doi.org/10.5821/ace.14.42.8362 }}$ 
Furlan, R. and L. Faggion. The Development of Vital Precincts in Doha: Urban Regeneration and SocioCultural Factors. In: American Journal of Environmental Engineering. 5(4),120-129, 2015.

Gregory, D. Suspended animation: the stasis of diffusion theory. In: Social relations and spatial structures. London: Macmillan. 1985, pp. 293-336.

Häusser, J. A., Kattenstroth, M., van Dick, R., \& Mojzisch, A. We are not stressed: Social identity in groups buffers neuroendocrine stress reactions. In: Journal of Experimental Social Psychology. 48(4), 973-977, 2012.

Hakim, B. Arabic Islamic Cities: Buildings and Planning Principles. In: Third World Planning Review. 8(4), $367,1985$.

Hamdan, G. The Pattern of Medieval Urbanism in the Arab world, In: Geography. 47, 121-134, 1962.

Ibrahim, H. Globalization Challenges in Contemporary Architecture to Support the Regional Identity, International Sustainable Tropical Environmental Design Conference 2013 (SusTED'13), Universiti Putra Malaysia, 18-19 December 2013. [Access data: 16 October 2018] Available at: <http://architectureurbanism.blogspot.com/2013/07/sustex-13-sustainable-tropical.html>

Ishii, H. T., Manabe, T., Ito, K., Fujita, N., Imanishi, A., Hashimoto, D., \& Iwasaki, A. Integrating ecological and cultural values toward conservation and utilization of shrine/temple forests in urban green space in Japanese cities. In: Landscape Ecology Engineering. 6, 307-315, 2010.

Jaidah I, and Bourennane M. History of Qatari Architecture 1800-1950. In: Skira, Italy. 2010, 336 p.

Knight, C. P. and Haslam, S. A. Your place or mine? Organizational identification and comfort as mediators of relationships between the managerial control of workspace and employees' satisfaction and well-being. In: British Journal of Management. 21, 717-735, 2014.

Lamit, H., Shafaghat, A., Majid, M. Z., Keyvanfar, A., Ahmad, M. H. B., \& Malik, T. A. (2013a). Grounded group decision making (GGDM) model. Advanced Science Letters, 19(10), 3077-3080.

Lamit, H. B., Shafaghat, A., Majid, M. Z., Keyvanfar, A., Ahmad, M. H. B., \& Malik, T. A. (2013b). The Path Walkability Index (PAWDEX) Model: To Measure Built Environment Variables Influencing Residents' Walking Behavior. Advanced Science Letters, 19(10), 3017-3020.

Lamit, H. B., Shafaghat, A., Majid, M. Z., Keyvanfar, A., Hamdan, M., Ahmad, B., ... \& Yadollahi, M. (2013c). Application of the Path Walkability Index (PAWDEX) Model: A Case Study of Retail Walking Pattern Recognition in Taman University Skudai, Johor, Malaysia. Advanced Science Letters, 19(10), 3021-3024.

Lapidus, I. M. The Evolution of Muslim Urban Society, in Comparative Studies in Society and History. In: Cambridge University Press. 1973, 15, pp. 21-50.

Larice, M. and E. Macdonald. Editors' introduction. In: The Urban design reader, ed. M. Larice and E. Macdonald, London: Routledge. 2007, 308-9.

Mahgoub, Y. and Abbara, B. Tall buildings legislations in Doha, Qatar. In: Procedia-Social and Behavioral Sciences. 36, 640-649, 2012.

ACE, 14 (42) CC BY-ND 3.0 ES | UPC Barcelona, España | Emerging Factors Shaping Identity Of Indigenous Urbanism Concurrently Adopting Modernity In Qatar: The Application Of Diffusion Theory. DOI $\underline{\text { http://dx.doi.org/10.5821/ace.14.42.8362 }}$ 
Qatar National Development Strategy 2011): Qatar General Secretariat for Development Planning, March 2011. [Access data: 22 April 2017] Available at: < http://www.gsdp.gov.qa/portal/page/portal/GSDP Vision Root/GSDP EN/NDS

Saoud, R. Urban Form, Social Change and the Threat of Civil War in North Africa. In: Third World Planning Review. 19(3), 289-312, 1997.

Schmitt, M. T., Davies, K., Hung, M., \& Wright, S. C. Identity moderates the effects of Christmas displays on mood, self-esteem, and inclusion. In: Journal of Experimental Social Psychology. 46, 1017-1022, 2010 .

Shafaghat, A., Keyvanfar, A., Ferwati, M. S., \& Alizadeh, T. (2015). Enhancing staff's satisfaction with comfort toward productivity by sustainable Open Plan Office Design. Sustainable Cities and Society, 19, 151-164.

Shafaghat, A., Manteghi, G., Keyvanfar, A., Lamit, H. B., Saito, K., \& Ossen, D. R. (2016a). Street geometry factors influence urban microclimate in tropical coastal cities: A review. Environmental and Climate Technologies, 17(1), 61-75.

Shafaghat, A., Keyvanfar, A., Manteghi, G., \& Lamit, H. B. (2016b). Environmental-conscious factors affecting street microclimate and individuals' respiratory health in tropical coastal cities. Sustainable Cities and Society, 21, 35-50.

Shafaghat, A., Keyvanfar, A., Majid, M. Z. A., Lamit, H. B., Ahmad, M. H., Ferwati, M. S., \& Ghoshal, S. K. (2016c). Methods for adaptive behaviors satisfaction assessment with energy efficient building design. Renewable and Sustainable Energy Reviews, 57, 250-259.

Southworth, M. and Ruggeri, D. Place, Identity And The Global City. In: Urban Design Companion to Urban Design. London: Routledge. 2010. [Access data: 4 July 2019] Available at: <https://www.routledgehandbooks.com/doi/10.4324/9780203844434.ch37

Taha, D. A. Place identity of egyptian cities: learning from the past, branding for the future. ACE: architecture, city and environment. [on line] February 2013, vol. 7, issue, 21, pages: 97-116. [Access data: 4 July 2019] Available at: < https://upcommons.upc.edu/handle/2099/13009>

Venturi, R. Complexity and Contradiction in Architecture. The Musium of Art. New York. Victor Scully. 1966. $132 \mathrm{p}$.

Venturi, R. and Scott Brown, D. Functionalism, Yes, But... In: A+U. 4(11), 47, 35-129, 1974.

Venturi, R., Robert, I. V., Brown, D. S., Izenour, S., \& Steven, R. V. D. S. B. Learning from Las Vegas. The Forgotten Symbolism of Architectural Form. Cambridge. 1977. 192 p.

ACE, 14 (42) CC BY-ND 3.0 ES | UPC Barcelona, España | Emerging Factors Shaping Identity Of Indigenous Urbanism 